\title{
Stratigraphical influence on chalk cave development in Upper Normandy, France: implications for chalk hydrogeology
}

\author{
Daniel Ballesteros (iD ${ }^{1}$, Andrew Farrant ${ }^{2}$, Carole Nehme (D) ${ }^{1 *}$, Mark Woods ${ }^{2}$, \\ Dominique Todisco (D) ${ }^{1}$, and Damase Mouralis (D) ${ }^{1}$ \\ ${ }^{1}$ UMR 6266 IDEES, University of Rouen-Normandy/CNRS, Mont Saint-Aignan CEDEX, France \\ ${ }^{2}$ British Geological Survey, Keyworth, Nottingham, NG12 5GG, United Kingdom
}

\begin{abstract}
Classically, the Upper Cretaceous Chalk Group aquifer of northwest Europe is conceptualized as a homogenous dual-porosity aquifer, with high porosity related to its fine-grained porous matrix, and intermediate hydraulic conductivity associated with fractures. However, an increasing number of hydrological studies visualize the Chalk as a heterogeneous karst aquifer due to the localised presence of dissolutionally enlarged conduits. Field investigation suggests that cave development is guided by distinct stratigraphical and tectonic discontinuities within the rock mass. Identifying which potential inception horizons within the Chalk aquifer are favoured, and why, is important for developing future robust conceptual models of groundwater behaviour. This study focusses on the Chalk of the Upper Normandy region in France where karstic conduits are common and are linked to major sources of groundwater for public water supply. We analyse the geometry and geomorphology of six chalk caves exposed in the Seine Valley with an aggregated length of over $5.7 \mathrm{~km}$, along with other caves in southern England, and identify the key inception horizons associated with their development. The data shows that prominent Turonian, Coniacian and Santonian hardgrounds have influenced the development of $68 \%$ of the studied caves length, with sheet-flints and marl seams also playing a prominent role. Caves developed on or between hardgrounds typically display a complex interlinked anastomotic passage network, whereas passages subjected to paragenetic conditions caused by a high sediment flux tend to be concentrated into fewer, larger conduits. The new evidence from Normandy and Southern England demonstrates the role of lithostratigraphy, and in particular stratigraphical discontinuities on conduit development. The data reinforces the idea that the Chalk aquifer should be viewed as a heterogeneous triple porosity karstic aquifer, in which conduit development is influenced by key stratigraphical discontinuities. This improved conceptual model can be used to develop better groundwater flow models and improved catchment delineation.
\end{abstract}

Keywords: $\quad$ cave, chalk, groundwater, hydrogeology, karst aquifer, speleogenesis

Received 27 March 2020; Revised 8 October 2020; Accepted 8 October 2020

Citation: Ballesteros D., Farrant A., Nehme C., Woods M., Todisco D. and Mouralis D., 2020. Stratigraphical influence on chalk cave development in Upper Normandy, France: implications for chalk hydrogeology. International Journal of Speleology, 49 (3), 187-208. Tampa, FL (USA) ISSN 0392-6672 https://doi.org/10.5038/1827-806X.49.3.2319

\section{INTRODUCTION}

The Upper Cretaceous Chalk Group of north-western Europe is a major groundwater aquifer covering over $120,000 \mathrm{~km}^{2}$ and supplying more than $60 \%$ of the drinking water of northern France, southeast England, Belgium, Denmark and the Netherlands (Price et al., 1993). It comprises a sequence of fine grained micritic limestones 300-600 m thick formed mainly by the accumulation of carbonate coccolithophores $(<10 \mu \mathrm{m}$ in size) and, locally, algae nannoconus and calcispheres (Mortimore, 2019). Therefore, the groundwater chemistry is dominated by $\mathrm{Ca}-\mathrm{HCO}_{3}$
(Valdes et al., 2014). Although it possesses a high primary porosity (14-46\%), hydraulic conductivities for bulk samples are generally very low even though measurements of transmissivity commonly exceed $1000 \mathrm{~m}^{2}$ day $^{-1}$ (Descamps et al., 2017). Values typically range between $10^{-4}$ and $10^{-2} \mathrm{~m}^{2}$ day $^{-1}$ (Price et al., 1976), although locally they can be higher, up to $0.28 \mathrm{~m} \mathrm{day}^{-1}$ (Rahman \& Rosolem, 2017; Thiéry et al., 2018). Much of the conductivity is within secondary porosity due to fracturing or dissolution (Arbonnier et al., 2004; Zouhri et al., 2009; Mougin et al., 2011). This accounts for the bulk of the specific yield (Price et al., 2000) and the hydraulic conductivity or transmissivity (Allen et 
al., 1997). Due to the high porosity of the rock matrix, the Chalk is normally considered as a dual-porosity or double-permeability aquifer (Butler et al., 2014; Azeez et al., 2015; Zghibi et al., 2016; Descamps et al., 2017; Hakoun et al., 2017). Storage is predominantly within the matrix. Up to $90 \%$ of the porosity is contained within pores $100-600 \mathrm{~nm}$ in size (Faÿ-Gomord et al., 2016), but hydraulic conductivities are low because the typical pore throat diameter of $0.5 \mu \mathrm{m}$ is too small to permit efficient flow (Price et al., 1976).

Traditionally, the Chalk is viewed as being a homogeneous medium, with flow and contaminant transport by a combination of slow matrix flow and more rapid fissure flow (Le Vine et al., 2016). The role of dissolution and the development of secondary karst permeability is often not considered or it is assumed to have a minor role in aquifer development (Roux et al., 2019). Nevertheless, dissolution cavities, sinking streams, conduits, sinkholes and other karst features have been reported in the Chalk (MacDonald et al., 1998; Laignel et al., 2004; Maurice et al., 2012; Grube et al., 2017). Lamont-Black and Mortimore (2000) described the role of mixing corrosion in the formation of karstic conduits related to hardgrounds, sheetflints and marl seams. In practice, in many areas, the functioning of the Chalk groundwater system is rather more similar to a karst aquifer than a granular or single porosity media (Bloomfield et al., 2013; Barhoum et al., 2014). Flow velocities measured from tracer tests can be $>300-400 \mathrm{~m} \mathrm{~h}^{-1}$ (Maurice et al., 2006; Keim et al., 2012) and spring discharges in excess of $5 \mathrm{~m}^{3} \mathrm{~s}^{-1}$ (Brenner et al., 2018). For these reasons, an increasing number of hydrogeological studies consider the Chalk as a triple porosity aquifer, with a combination of fracture and matrix porosity, and localized karst permeability (Mangin, 1975; Pennequin et al., 2017), or just as a karst aquifer in which karstification is less well developed than in other more massive and indurated limestones (Maurice et al., 2006; El Janyani et al., 2014).

Notwithstanding the above, the Chalk aquifer is still far too often visualized as a homogeneous porous medium (Brenner et al., 2018), rather than a karstic aquifer. Only a few studies have considered the role of lithological heterogeneity and stratigraphical discontinuities on groundwater flow (Descostes et al., 2012; Gallagher et al., 2012; Barhoum et al., 2014).

In many karst aquifers, the role of lithology on conduit development can be evaluated through the direct exploration of active conduits. Hydrologically active caves offer a window on contemporary groundwater flow within the aquifer. Whilst large springs are common in the Chalk, indicating the existence of significant conduit systems, the conduits feeding them are usually inaccessible. Most are blocked by sediment, too small to enter, or rendered inaccessible by public water supply infrastructure. An alternative way to investigate the role of lithology on karst development in the chalk aquifer is through the direct investigation of relict chalk caves. Caves are protected from surface erosion and degradation, and preserve evidence of past flow history and conduit development over long timescales.
In this paper, we examine the role of Chalk lithology on karst development through the study of relict caves in the lower Seine Valley in northern France. Over 6 $\mathrm{km}$ of Chalk caves have been explored and surveyed in the region (Rodet, 2007). We combine a detailed analysis of the geometry and geomorphology of six study caves totalling $5.7 \mathrm{~km}$ in length with a study of karstic conduits exposed on coastal cliff sections in Normandy and southern England. The stratigraphical position of these caves and conduits is assessed using a high resolution stratigraphical framework, which enables us to identify the key lithological horizons that guide conduit development. Additional evidence from springs and other caves are also used. Not only do caves provide evidence of stratigraphical guidance of groundwater flow (Lowe, 2000), but the cave geomorphology also yields information on the paleohydrology of the aquifer (Palmer, 1991). Caves formed in the phreatic and epiphreatic zones have a distinctive passage morphology, and past flow directions can be ascertained through the examination of asymmetric dissolutional flow markings known as scallops. The wider geomorphological and hydrogeological setting can be derived from the geometry, spatial and vertical distribution of conduit networks (Nehme et al., 2020).

\section{SETTING}

The Upper Normandy region of northern France (Fig. 1A, B) comprises an extensive plateau developed at an elevation of $100-200 \mathrm{~m}$ above sea level (asl). This plateau is incised to a depth of $\sim 100 \mathrm{~m}$ by the Seine River, a major river system that drains much of northern France with a catchment area of $\sim 76,000$ $\mathrm{km}^{2}$. The region has a temperate maritime climate, with mean monthly temperatures between 3 and $17^{\circ} \mathrm{C}$, and $600-1100 \mathrm{~mm}$ annual precipitation.

Around $90 \%$ of the region is underlain by the Upper Cretaceous Chalk Group, a sequence of flinty limestones up to $350 \mathrm{~m}$ thick deposited on the western margin of the Anglo-Paris Basin (Lasseur et al., 2009; Mortimore, 2019). The geological structure is relatively subdued, characterised by gentle folds with sub-horizontal bedding $\left(<10^{\circ} \mathrm{dip}\right)$, and punctuated by occasional large faults with up to $200 \mathrm{~m}$ of displacement occurring during the Turonian to the late Miocene (Duperret et al., 2012; Gupta et al., 2017). Around 90\% of the Chalk is covered by Cenozoic and Quaternary sediments up to $50 \mathrm{~m}$ thick. These comprise outliers of Paleogene sand and clay, Pliocene-early Pleistocene marine and fluvio-marine sand preserved in karst depressions (Hauchard \& Laignel, 2008), up to $40 \mathrm{~m}$ of Clay-with-Flints derived from the in-situ weathering of the Paleogene cover (Catt, 1986; Quesnel et al., 2003), Quaternary fluvial terrace deposits, and Upper Pleistocene loess deposits up to $5 \mathrm{~m}$ thickness (Antoine et al., 2016).

\section{Chalk stratigraphy}

The dominant lithology of the Chalk Group is rhythmically bedded, bioturbated coccolithic biomicrite with variable minor amounts of foraminifera, 


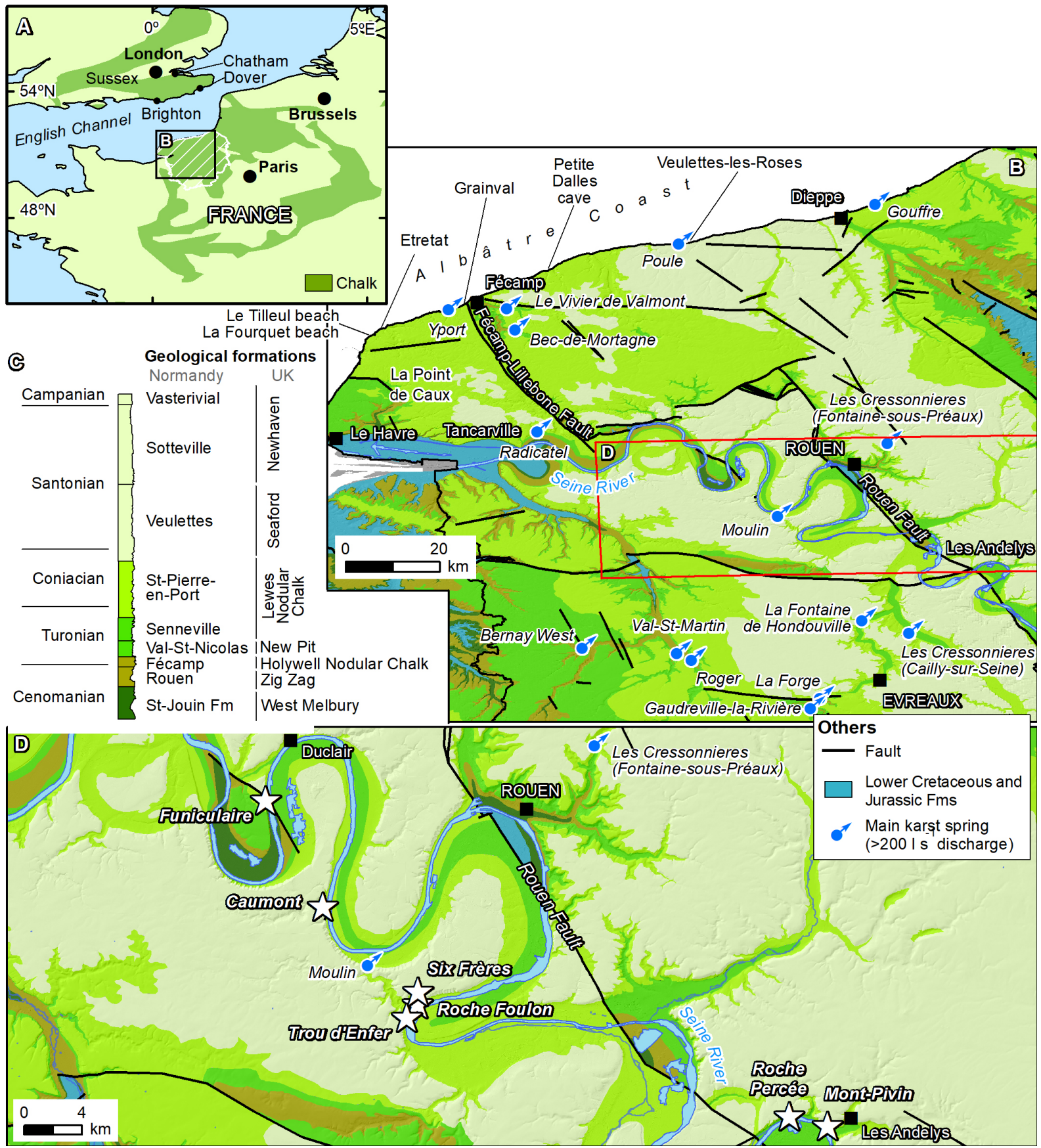

Fig. 1. A) Location of the Chalk Group outcrop in northwest Europe; B) Geological map of the Chalk Group, Upper Normandy. Around $90 \%$ of the Mesozoic bedrock is covered by Cenozoic rocks and Quaternary sediments; C) Generalized stratigraphical vertical section with Norman geological formations detailed in Fig. 2; D) Study caves in the lower Seine Valley. Geology is based on data courtesy of BRGM (Van Lint et al., 2003; Quesnel et al., 2008).

ostracod and bryozoan debris (Quince \& Bosence, 1991; Mortimore et al., 2001). Locally inoceramid, echinoderm and crinoid debris form more calcarenitic beds (Kennedy \& Juignet 1974). The succession is punctuated by numerous regionally extensive lithostratigraphical horizons including hardgrounds, sponge beds, marl seams, and various types of flint bands (semi-tabular, nodular and sheet-flints). Some are local in extent, sometimes arranged in complex 3D geometries; others are more regional scale or basin-wide features (Woods, 2015; Mortimore, 2019). They have an important role in the development of dissolutionally enlarged conduit systems, forming potential inception horizons along which dissolution is focused (Lowe \& Gunn, 1995; Lowe, 2000). Hardgrounds, marl seams and sheet flints constitute beds with low permeability compared to other parts of the succession (Saïag, 2016; Saïag et al., 2019), hence they represent permeability barriers within the Chalk aquifer (Van Buchem et al., 2017; Gaillard et al., 2018). These barriers are mainly sub-horizontal due to the relative little effect of the Alpine/Pyrenean deformation in the Anglo-Paris Basin.

Hardgrounds result from depositional and early diagenetic events associated with reduced sedimentary rates and long sea-floor exposure during periods of low sea-level (Kennedy \& Garrison, 1975; Bromley \& Gale, 1982). They are characterized by a thin zone of cemented, nodular, bored chalk typically $5-20 \mathrm{~cm}$ thick, often mineralized by glauconite and phosphate (Quince \& Bosence, 1991; Juignet \& Breton, 1992). They are a common feature in the Normandy area, reflecting the basin margin setting. More than fifty hardgrounds are recognised in the Cenomanian to 
middle Turonian chalks (Juignet \& Breton, 1992; Lasseur et al., 2009; Gale, 2019), with a further thirty hardgrounds in the upper Turonian to lower Campanian chalks (Hoyez, 2008). Fewer hardgrounds occur in more basinal Chalk sequences further north and east, and across the English Channel in southeastern England. Locally several hardgrounds may coalesce to form a thick unit of chalkstone up to 2-3 m thick, such as the 'Chalk Rock' of the Chiltern Hills in England. Sponge beds are similar to hardgrounds in that they represent hiatuses in sediment deposition, enabling colonization of the sea-floor by sponges (Quince \& Bosence, 1991). They are characterized by indurated, often iron stained horizons with fossil sponge remains.

Marl seams are thin concentrations of terrigenous clay or in some cases bentonitic ash fall deposits (Wray, 1999) typically a few $\mathrm{cm}$ thick. Some form distinctive marker beds which can be correlated across the Anglo-Paris Basin (Mortimore, 2019; Gale, 2019). Their occurrence and thickness vary both spatially and temporally through the sequence, thinning over structural highs. They are common in certain parts of the succession, notably the Val-St-Nicolas, StPierre-en-Port and Sotteville (New Pit, Lewes Nodular and Newhaven Chalk) formations, and in the lower Veulette (Seaford Chalk) Formation.

Flint bands are common and take several forms. The most common are nodular flints typically 5-40 $\mathrm{cm}$ in diameter arranged in horizontal bands spaced at regular intervals of $0.4-1 \mathrm{~m}$ apart through the succession from the Cenomanian to the lower Campanian (Quince \& Bosence, 1991). The succession in Normandy is particularly flinty compared to southern England where flints are absent in the Cenomanian and early Turonian (Mortimore, 2019). Sometimes, flint forms semi-tabular bands, some of which represent identifiable basin-wide marker beds such as the Coniacian Seven Sisters Flint band (Mortimore \& Pomerol, 1987). Sheet-flints are a particularly distinctive type of flint formed by the early silicification of shear planes and other fractures during diagenesis. They form continuous sheets of flint 1-10 $\mathrm{cm}$ thick along existing discontinuities, such as bed parallel slides (Mortimore, 2011), extending laterally for tens to hundreds of metres, and exceptionally kilometres. They are particularly prevalent in the StPierre-en-Port (Lewes Nodular Chalk) Formation.

Other discontinuities were formed during diagenesis and compression including stylolites (Mortimore, 2011, 2019) and fracture networks. Mortimore \& Pomerol (1987) demonstrated that intra-Cretaceous tectonism influenced sediment thickness, chalk lithology and fracture style; factors that are important for karst development.

In the lower Seine Valley, the Chalk Group can be divided into nine formations (Figs. 1 and 2), which are well exposed on the coast (Hoyez, 2008). These formations are correlated with the Chalk stratigraphy in southern England (Hopson, 2005; Mortimore, 2011; Gale, 2019). The engineering and hydrogeological properties of each formation vary depending on lithology, the number and extent of stratigraphical discontinuities, fracture style, and fracture characteristics including tightness, volume, connectivity and degree of infilling (Mortimore, 1993).

\section{Chalk aquifer and cave development}

In Upper Normandy, the Chalk constitutes a single karst aquifer 50-350 $\mathrm{m}$ thick and over $12,000 \mathrm{~km}^{2}$ in extent. The aquifer is cut by faults that compartmentalize the aquifer into blocks with minor differences in behaviour (Slimani et al., 2009; Pennequin et al., 2017). The water table elevation varies across the region from 0 to $35 \mathrm{~m}$ altitude. The unsaturated zone is up to $\sim 150 \mathrm{~m}$ thick whilst the saturated zone reaches a maximum of $350 \mathrm{~m}$ thickness in the central part of the Normandy plateau (Mougin et al., 2011). Water tables and hydraulic gradients dip $\sim 1^{\circ}$ or less towards the Seine River and to the coast. Fluctuations in the water table show multi-year variations linked to climatic conditions and, near the coast and adjacent to the Seine Estuary, daily oscillations related to tide (Fournier et al., 2008; Slimani et al., 2009).

Recharge is influenced by the thick low permeable superficial deposits that cover much of the Chalk (Valdes et al., 2014). Where the cover is particularly thick or consists of very low permeable clay, the aquifer recharge is restricted (El Janyani et al., 2012, 2014). In areas where the superficial deposits are thinner, or around the feather edge of Paleogene detrital rocks, recharge is more focused, favouring the development of karst features such as stream sinks, sinkholes (known locally as 'bétoires') and sedimentfilled dissolution pipes. Where the superficial cover is very thin or absent, recharge to the underlying chalk is more diffuse (El Janyani et al., 2014; Valdes et al., 2014). In these areas, dissolution still occurs, but is distributed across many potential flow paths, rather than being focused in a few specific locations.

Once surface recharge infiltrates down to the Chalk, flow through the vadose zone is predominantly via vertical or sub-vertical conjugate fractures (El Janyani et al., 2014), or more rarely open shafts (Chédeville et al., 2015), with a slower component migrating down to the water table via the rock matrix. On reaching the water table, groundwater flow changes to quasihorizontal conduits and fracture systems to reach springs in the major valleys or along the coast (E1 Janyani et al., 2012, 2014). Flow velocities of 300-400 $\mathrm{m} \mathrm{h}^{-1}$ have been recorded over pathways longer than $10 \mathrm{~km}$ (Fournier et al., 2008). Aquifer discharge takes place mainly through the alluvial aquifers of Seine Valley (Weng et al., 1999) and via karst springs. Some springs associated with known karst conduits as the Yport spring have discharges up to $2.5 \mathrm{~m}^{3} \mathrm{~s}^{-1}$ (Fig. 1B) (Roux et al., 2019).

Whilst the occurrence of karst conduits in Normandy has long been known (Rodet, 2007, 2013), little attempt was made to systematically relate the development of these conduits to Chalk stratigraphy. Recently, Gaillard et al. (2018) highlighted the role of facies variability and the Tilleul 2 and other hardgrounds in the Senneville and Pierre-en-Port formations in the location of coastal springs at La 


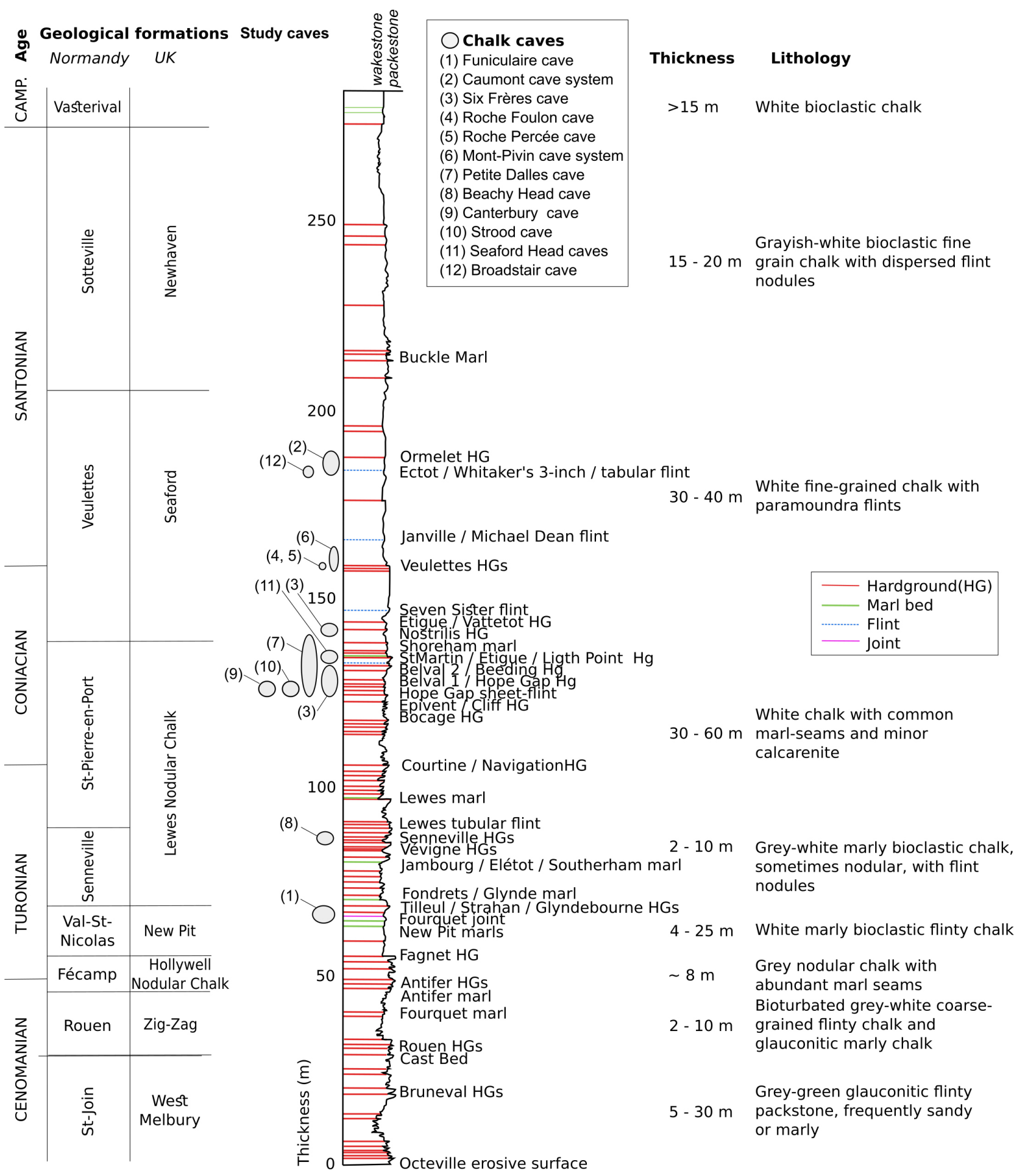

Fig. 2. Synthetic stratigraphical section of Upper Cretaceous Chalk Group of Normandy based on Lasseur et al. (2009), Hoyez (2008), Mortimore (2011, 2019), Gale (2019). Position of the study caves in Normandy and Southern England is indicated in the stratigraphical section. St-Jouin and Senneville formations were defined by Juignet \& Breton (1992), Rouen Fm by Juignet (1980), Fécamp and Val-StNicolas formations by Lasseur et al. (2009), and St-Pierre-en-Port, Veulettes, Sotteville and Vasterival formations by Juignet (1991).

Point de Caux (Fig. 1B). The conduit systems were developed on hardgrounds but focused along the axis of synsedimentary channels. Around thirty karst caves with an aggregate explored length of $\sim 6 \mathrm{~km}$ are documented in the lower Seine Valley (Rodet, 2007). These epigenic, mostly relict cavities are characterized by sub-horizontal anastomotic networks of partially or totally sediment-filled passages converging into larger tubular or elliptical galleries, forming branchwork cave networks (Palmer, 1991).

Cave development is linked to the Quaternary incision of the Seine River, which defines the regional base level. During the last one million years, repeated phases of cave formation, cold-stage valley incision and subsequent terrace aggradation, followed by renewed conduit development has created a stacked sequence of ancient cave levels preserved between 5 and $100 \mathrm{~m}$ altitude above current base level (Nehme et al., 2020). Cave development is also influenced by the influx of sediment into the conduit system from the overlying Cenozoic cover (Chédeville et al., 2015). Sediment is entrained into the conduit system via dissolution pipes, stream sinks and sinkhole collapse. Repeated influxes of sediment into phreatic conduits causes dissolution to be focused upwards on the conduit ceiling as the passage floors are mantled with sediment. 
Over time, this leads to the upwards enlargement of the conduit, a process known as paragenesis (Farrant \& Smart, 2011; Nehme et al., 2020), also named per ascensum speleogenesis (Mocochain et al., 2009) or antigravitative erosion (Pasini, 2009). Paragenetic cave development is common in the Normandy chalk caves. Many of the known caves have been discovered through the excavation of the sediment infilling the cave systems (Rodet \& Staigre, 2019).

\section{METHODOLOGY}

To determine the role of stratigraphical heterogeneity on conduit development and aquifer function, six karst caves were studied in detail. Additional evidence was obtained from six caves and conduits elsewhere in Normandy and southern England. For each cave, a detailed cave survey was produced, followed by geomorphological and morphometric analysis of the passage and sediments.

The caves were surveyed using standard cave surveying methods, which involve measuring the distance, direction and inclination between successive survey stations within the cave using a DistoX2 laser range-finder that incorporates a digital compass and inclinometer. The heights and widths of the passages were also measured at each survey station. The raw survey data were computed using Compass software to create the georeferenced survey in a geographical information system (GIS) (ArcGIS 11.3). The precision of the cave surveys was estimated in 1-3\% using closed survey loops.

The geomorphological analysis involved identifying the mode of cave formation from passage morphology, distinguishing between phreatic, epiphreatic, paragenetic and vadose phases. The cave surveys were used to classify the plan pattern of each cave into branchwork and maze types following the scheme outlined by Palmer (1991). The palaeo-hydrology of each cave system was deduced from flow direction indicators including scallops, passage geometry and gradient, and, where present, sedimentary structures such as cross bedding and ripple marks recognised in the cave infill (Ballesteros et al., 2019; Pennos et al., 2019).

The stratigraphical position of the cave within the Chalk Group was identified in order to establish the geological context of each cave. This was done by identifying key marker beds and biostratigraphy. The stratigraphy is based on sections exposed along the Normandy coast, and from inland sections and shown on geological maps (Quince \& Bosence, 1991; Juignet and Breton, 1992; Van Lint et al., 2003; Hoyez, 2008; Quesnel et al., 2008; Lasseur et al., 2009; Mortimore, 2011, 2019; Gale, 2019). Additional data was derived from more detailed, targeted geological mapping of the area and detailed section logging at key sites including within the caves. Petrographical analysis of 17 thin sections was used to integrate the existing geological map. Profiles of each cave were extracted from the cave survey data and projected onto high-resolution stratigraphical sections.

Finally, we quantified the 3D geometry of the study caves using 14 key morphometric parameters (Klimchouk, 2006; Piccini, 2011) to establish a relationship between the cave geometry and Chalk stratigraphy (Table 1). These morphometric parameters are related to the hydrogeological and geomorphological context of the caves, and can be used to distinguish, for instance, between confined or unconfined settings (Klimchouk, 2006). In many caves, the presence of thick sediment fills obscured the 3D geometry of the conduit, so in some cases values are estimated from the contextual setting of the cave.

Table 1. Morphometric parameters and indices described in Ballesteros et al. (2015) and selected from Klimchouk (2006) and Piccini (2011).

\begin{tabular}{|l|c|c|c|}
\hline Parameter/Index & Symbol & Value & Calculation method \\
\hline Real length & Lr & Cave conduits 3D length & Sum of the distances between survey stations \\
\hline Plan length & Lp & 2D Length of cave conduits projected on a plan & $\begin{array}{c}\text { Sum of the distances between survey stations } \\
\text { projected on a plan }\end{array}$ \\
\hline Vertical range & VR & Cave vertical dimension & $\begin{array}{c}\text { Altitude difference between the highest and } \\
\text { lowest cave passage }\end{array}$ \\
\hline Cave area & Ac & Cave floor area & $\begin{array}{c}\text { Area enclosed by the conduit contours from the } \\
\text { cave survey }\end{array}$ \\
\hline Cave volume & Vc & Cave conduits volume & Sum of the prisms volume of the cave 3D model \\
\hline Asymmetry ratio & R & Cave conduits shape & $\begin{array}{c}\text { Average of the quotient between wide and high } \\
\text { of the conduits per meter of Lr }\end{array}$ \\
\hline Specific volume & SV & Ratio between the cave volume and real length & $\begin{array}{c}\text { SV=Vr } / \text { Lr } \\
\text { polygon that enclose the cave plan (minimum } \\
\text { convex polygon) }\end{array}$ \\
\hline Passage density & D & Ratio of cave conduits per karst surface & $\begin{array}{c}\text { Quotient between the Ac and the area of the } \\
\text { polygon that enclose the cave plan (minimum } \\
\text { convex polygon) }\end{array}$ \\
\hline Areal coverage & Ac & Ratio between cave surface and karst extension \\
\hline Cave porosity & Pc & Percentage of the karst occupied by the cave & $\begin{array}{c}\text { Quotient between the Vc and the volume of the } \\
\text { 3D cuboid that enclose the cave }\end{array}$ \\
\hline Vertical index & VI & Cave verticality grade & VI=VR/Lr \\
\hline Horizontal index & HI & Cave horizontality grade & HI=Lp/Lr \\
\hline $\begin{array}{l}\text { Complex horizontal } \\
\text { index }\end{array}$ & HCI & Cave horizontality and tortuosity grade & $\begin{array}{c}\text { CHI=Lp/Ex, where Ex is the plan distance } \\
\text { between the farther passages of the cave }\end{array}$ \\
\hline Linearity index & LI & Cave tortuosity/sinuosity grade & \begin{tabular}{c} 
LI=(2 Ex+3 VR) 0.5/Lr \\
\hline
\end{tabular} \\
\hline
\end{tabular}




\section{RESULTS}

\section{Relations between study caves and bedrock stratigraphy}

Funiculaire Cave

The entrance of the Funiculaire Cave $\left(49^{\circ} 26^{\prime} 39.70^{\prime \prime} \mathrm{N}\right.$, $0^{\circ} 51$ '14.56”E) is located on the outer, north bank of the Jumièges meander, $16 \mathrm{~km}$ downstream of Rouen (Fig. 1D). The cave is $360 \mathrm{~m}$ long and characterised by a quasi-horizontal anastomotic network of small relict phreatic/epiphreatic conduits that lead off a single larger gallery (Fig. 3). Later fluvial incision modified the main gallery creating a vadose trench that was later filled by more than $2 \mathrm{~m}$ of detrital sediments, mostly allochthonous clay and silt with some sand, together with autogenic flint pebbles derived from passage breakdown. Scalloping and passage geometry suggest groundwater flow was to the southeast (Coquerel et al., 1993).
Funiculaire Cave is located within the upper part of Val-St-Nicolas Fm, which comprises a white bioclastic wacke- to packstone chalk with stratified flint nodules and marl seams (Fig. 3B, C). The ceiling of the main gallery follows the Tilleul 1 and Tilleul 2 hardgrounds (Kennedy \& Juignet, 1974), which are each $20-40 \mathrm{~cm}$ thick and of regional extent. The hardgrounds are characterised by green glauconitic and phosphatic nodules perforated by non-indurated burrows (Fig. 3D, E). Other stratigraphical markers include nodular chalk with burrow-form flints (Chrondrites), the Fourquet joint and the Antifer Flint defined by Hoyez (2008) at Le Tilleul beach (Fig. 1B). The latter marl and flint couplet are observed in the small labyrinthine passages below the main conduit and influence the development of these galleries (Fig. 3B). The main passage initially developed along the top or within the hardgrounds and on the Forquet joint, before enlarging by vadose incision and paragenesis.
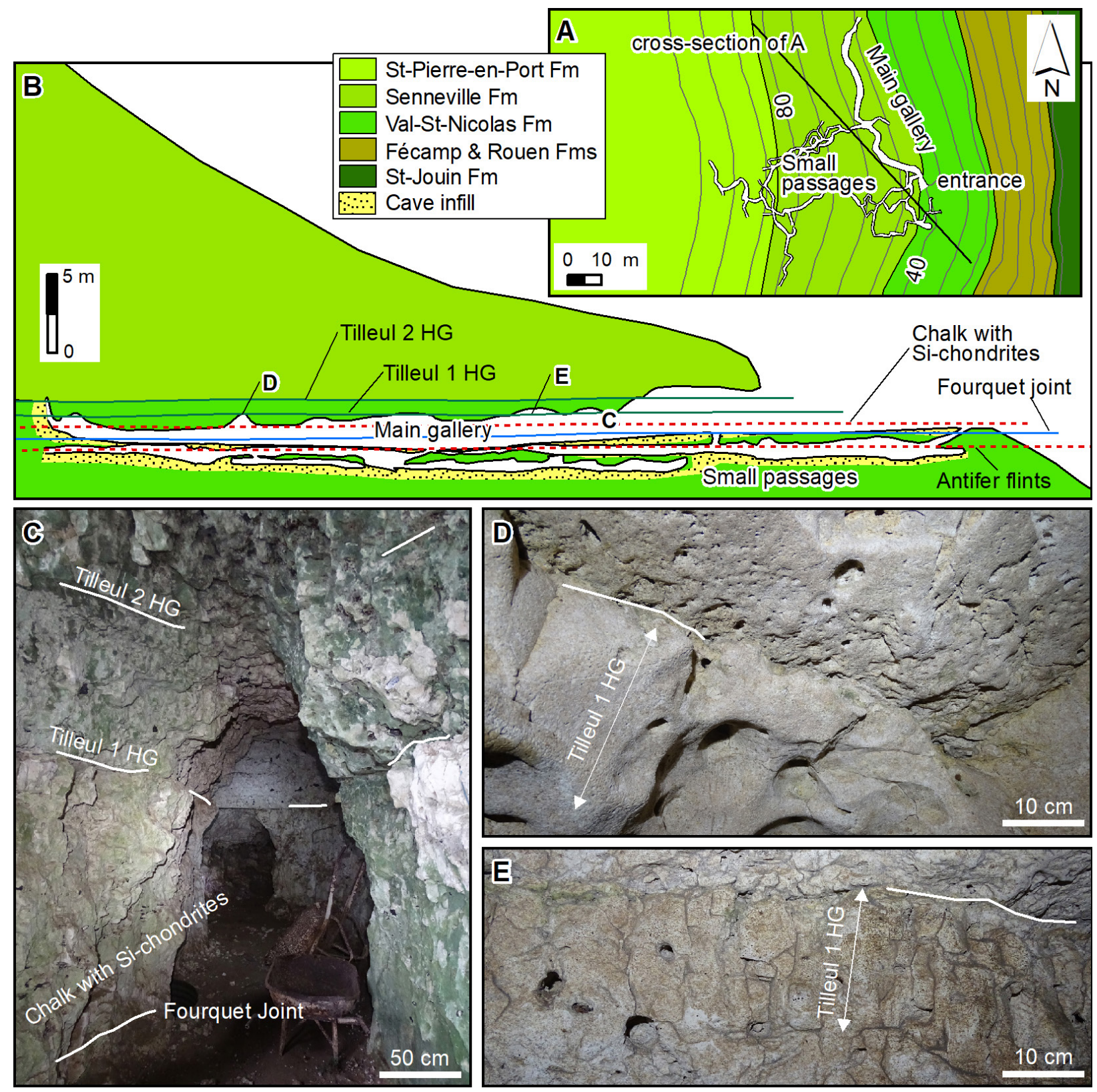

Fig. 3. A) Geological map of the Funiculaire cave area (the location of which is shown in Fig. 1D); B) Cave profile plotted on the geological cross-section highlighting stratigraphical horizons that influence the geometry of the cave; C) Entrance of the cave displaying the Tilleul hardgrounds (lines represents the top of each hardground), (Kennedy \& Juignet, 1974), chalk with silicified chondrites, and the Fourquet joint surface defined by Hoyez (2008); D) Tilleul 1 Hardground limiting the top of the main phreatic/ epiphreatic gallery; E) Vertical section of Tilleul 1 hardground highlighted by the presence of green glauconite and phosphatic nodules. 


\section{Caumont cave system}

The Caumont cave system (49 $\left.22^{\prime} 41^{\prime \prime} \mathrm{N}, 0^{\circ} 54^{\prime} 47^{\prime \prime} \mathrm{E}\right)$ is developed on the south bank of the Caumont meander $25 \mathrm{~km}$ southwest of Rouen (Fig. 1D). It comprises a maze network of passages $4.1 \mathrm{~km}$ long with $60 \mathrm{~m}$ vertical range discovered and partially truncated during the excavation of an underground quarry. Two cave levels can be identified: an upper level at $\sim 50 \mathrm{~m}$ altitude comprising $230 \mathrm{~m}$ of relict phreatic galleries; and a more extensive lower series with ca. $3.9 \mathrm{~km}$ of passage (Robots Stream, Jacqueline Cave and other passages) at 11-18 $\mathrm{m}$ asl. Both levels are linked by vadose vertical shafts such as the Trou de Chien shaft. The main lower level conduit is a $2.4 \mathrm{~km}$ long passage at an elevation of $\sim 15 \mathrm{~m}$ asl (Fig. 4A), descending gradually to the northeast. In the northwest part, this conduit is occupied by the
Robots Stream (<3 $\mathrm{L} \mathrm{s}^{-1}$ discharge), flowing to the northeast. The Robots stream has incised a vadose canyon 2-3 $\mathrm{m}$ deep beneath the initial phreatic conduit (Fig. 4B). The survey of the caves, allowing for segments removed by quarrying or infilled with sediments and/or quarry waste, reveals a branchwork system. In general, scallops preserved on the conduit walls indicate that ancient groundwater flowed to the northeast. The passage was largely filled with clay, silt and sand, capped by speleothem and breakdown deposits (Nehme et al., 2020). Part of this sediment fill has been removed, leaving remnants of speleothem false floors in some parts of the system between the Trou du Chien and Jacqueline passages (Fig. 4B). The downstream end of the cave stream terminates in a sump connected with the Seine River.

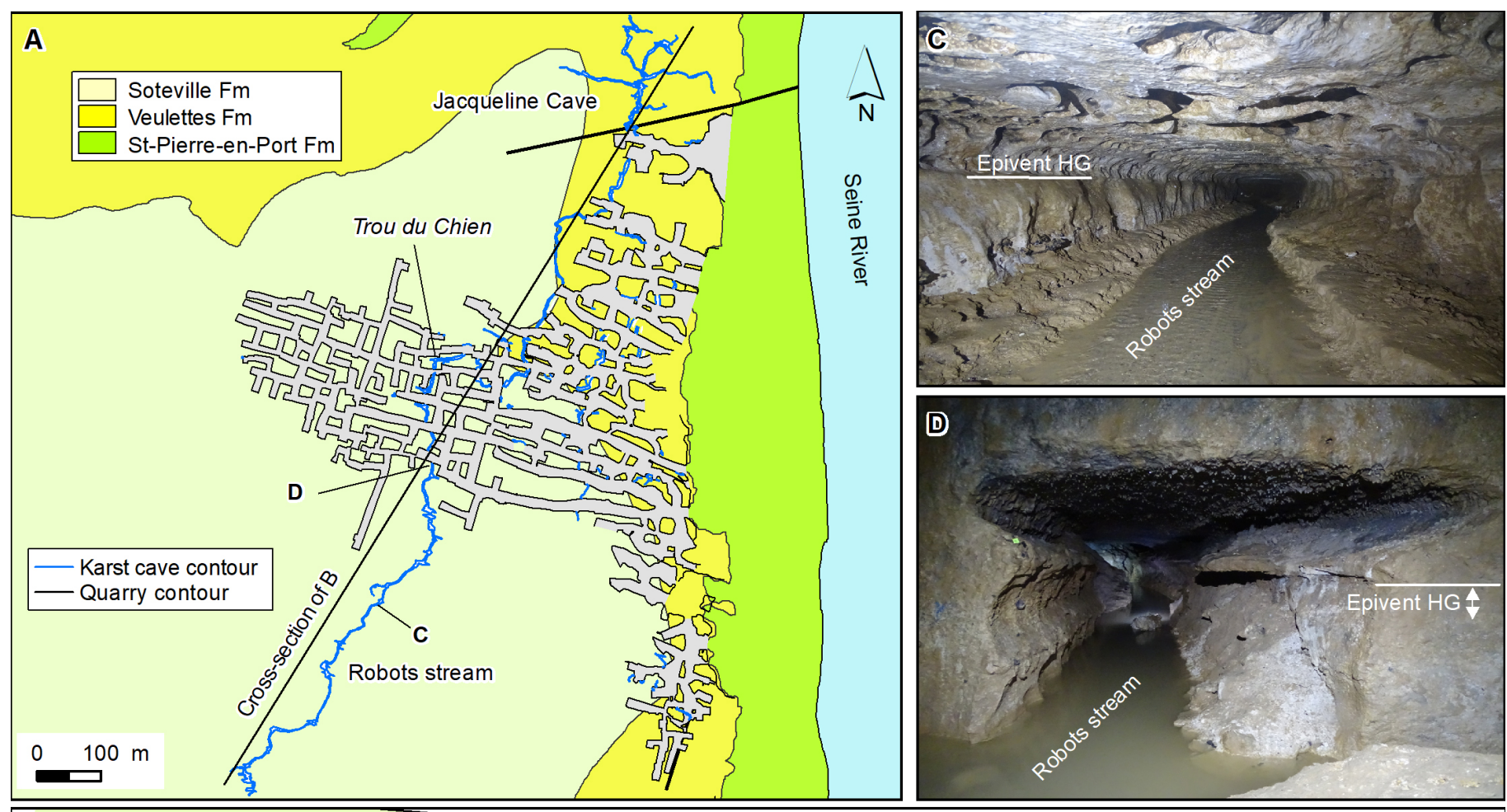

B

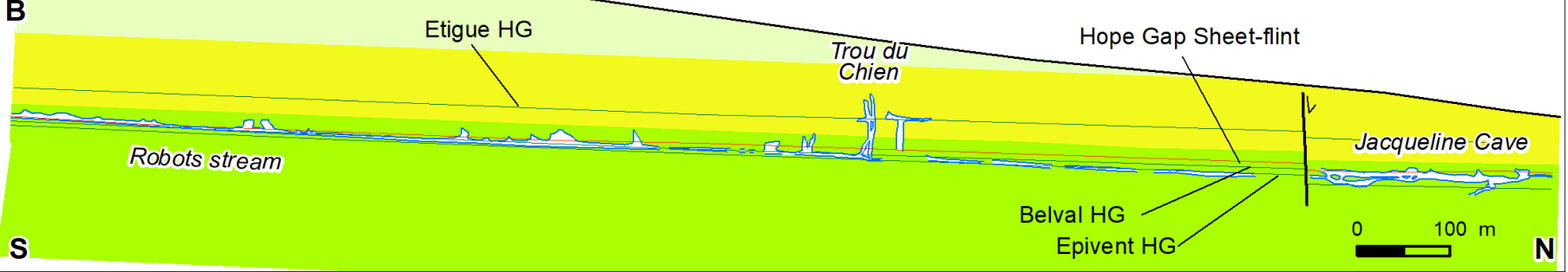

Fig. 4. A )Plan view of the Caumont cave system and quarries plotted on the geological map. Cave position is indicated in Fig. 1D; B) Geological profile of Caumont cave system, showing the Etigue, Epivent and Bocage hardgrounds and the Hope Gap sheet flint; C) Section along the Robots streamway following the Epivent hardground; D) Intersection between the Robots Stream gallery and Caumont quarry showing the Epivent hardground (the top is represented by a line). A normal fault located in the northernmost part of the cave system produced a $10 \mathrm{~m}$-vertical displacement.

The Caumont cave system is developed at the top of St-Pierre-en-Port Fm and the base of the overlying Veulettes Fm (Fig. 4A, B). Both geological units crop out in the side of the Seine Valley between Tancarville and Les Andelys (Fig. 1D). In the Caumont area, the chalk is a dedolomitized bioclastic packstone. The key stratigraphical markers identified in the bedrock include the Shoreham Marl, five hardgrounds, abundant marl seams and one or two prominent sheet-flints which are at the same stratigraphical level as the Hope Gap sheet-flint identified in Sussex, UK (Fig. 1A; Mortimore, 2019). The chalk dips $1-2^{\circ}$ to the SW, in the opposite direction to the Robots Stream, which flows to the northeast. The upperlevel of Caumont cave system coincides with the Etigue hardground while the lower level is developed along the Hope Gap sheet-flint and the Belval and Epivent hardgrounds (Fig. 4B), which can be observed on the Normandy coast (Hoyez, 2008). The Epivent hardground (Hoyez, 2008 ) is $20 \mathrm{~cm}$ thick and associated with flint nodules 
20-30 cm in diameter. It can be correlated with the Cliffe hardground in Sussex, UK (Fig. 1A) (Mortimore, 1986), while the Bocage hardground is of more local extent (Hoyez, 2008). The south-western end of the known cave passages is developed on the Hope Gap sheet-flint and on the top of Belval hardground (Fig. 4C), with the conduit passing down to the Belval and Epivent hardgrounds in the centre part of Caumont system (Fig. 4D). Minor faulting drops the Hope Gap sheet-flint back down to the Jacqueline cave level at the northern end of the quarry (Fig. 4B).

\section{Six Frères Cave}

Six Frères Cave $\left(49^{\circ} 14^{\prime} 51.30^{\prime \prime} \mathrm{N}, 1^{\circ} 23^{\prime} 43.66^{\prime \prime} \mathrm{E}\right)$ is situated on the side of a dry valley near Orival (Fig. 1D). It comprises a large phreatic/epiphreatic entrance gallery $17 \mathrm{~m}$ long with sediments exposed on the floor, with a smaller phreatic passage leading off at floor level. This small passage is $59 \mathrm{~m}$ long, and has some minor vadose modification (Fig. 5A). In plan view, the cave survey indicates a branchwork pattern. The cave is located at the top of Veulette Fm, of middle Santonian age, and comprises white bioclastic wackestone chalk with abundant stratified flint nodules. This part of the succession contains the well-developed 20-30 cm thick Ormelet hardground (Fig. 5B) and the Ectot tabular flint beds (around 5-10 $\mathrm{cm}$ thickness) as defined by Hoyez (2008). The position of the main gallery of Six Frères cave is coincident with hardground, with a breakout dome formed by collapse extending upwards, while the small galleries are related to the tabular flint beds (Fig. 5C).

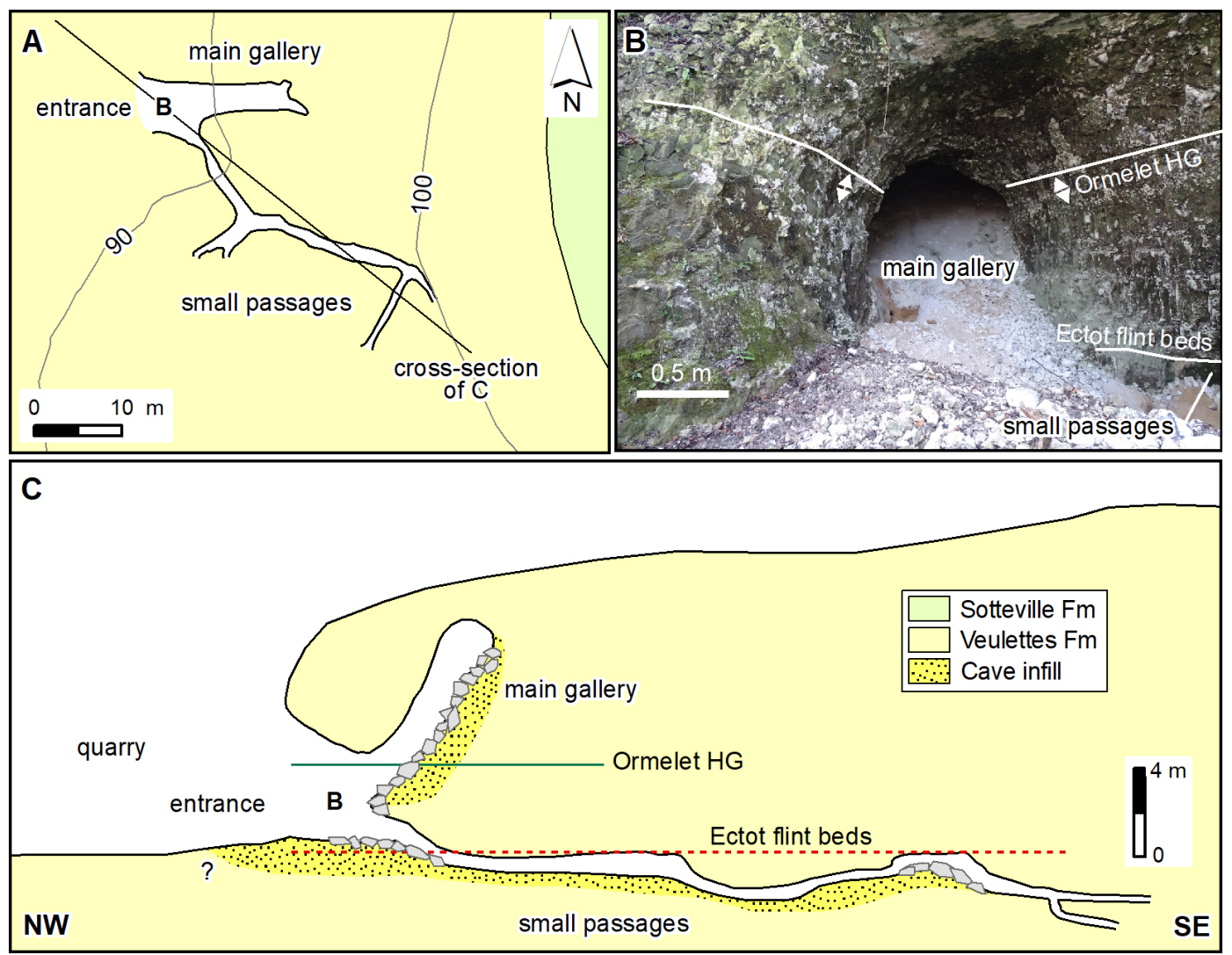

Fig. 5. A) Plan view of Six Frères Cave plotted on the geological map. Cave position is shown in Fig. 1D; B) Main gallery of the cavity influenced by the Ormelet hardground; C) Geological section of Six Frères cave showing the Ormelet hardground (the line represents its top) and Ectot flint beds. The main gallery $\left(\sim 40^{\circ}\right.$ inclination) shows a higher apparent slope due to its projection on an oblique cross-section.

\section{Roche Foulon Cave}

The Roche Foulon Cave (49¹9'7.5” N, 1 $\left.{ }^{\circ} 00^{\prime} 13.1^{\prime \prime E}\right)$ is located at the Cléon meander $15 \mathrm{~km}$ south of Rouen (Fig. 1D). The cavity comprises phreatic/epiphreatic passages $170 \mathrm{~m}$ long, developed on two levels at 82 and $88 \mathrm{~m}$ altitude, connected by small sub-vertical to inclined vadose conduits (Fig. 6A). The passages are largely infilled with clay, silt and sand which have been partially excavated by speleologists (Chédeville et al., 2015). Over $2 \mathrm{~m}$ of sediment is preserved in a section at the southern entrance, with several other 0.5 to $1 \mathrm{~m}$ sections elsewhere in the cave. The influx of sediment has led to paragenetic overprinting and continued upwards enlargement of the passage (Nehme et al., 2020).

The cave is developed in the middle part of the Veulette Fm, which comprises white bryozoan wackstone chalk with stratified flint nodules. Phreatic/epiphreatic conduits were developed above two hardgrounds $0.5 \mathrm{~m}$ apart (Fig. 6B-E), a thick nodular flint band and a sheet-flint. These three stratigraphical markers are concentrated in a zone of Chalk $4 \mathrm{~m}$ thick. This association suggests that the hardgrounds seen in the cave are the Veulettes hardgrounds defined by Hoyez (2008) in Veulettes-les-Roses on the coast (Fig. 1D). The hardgrounds, typically $20-30 \mathrm{~cm}$ thick, are located between the Michel Dean and Seven Sisters flints, two well-developed semi-continuous nodular flints that occur widely across the Anglo-Paris Basin (Mortimore \& Pomerol, 1987). The cave initially developed on these stratigraphical horizons, and then enlarged upwards under paragenetic conditions (Nehme et al., 2020). 


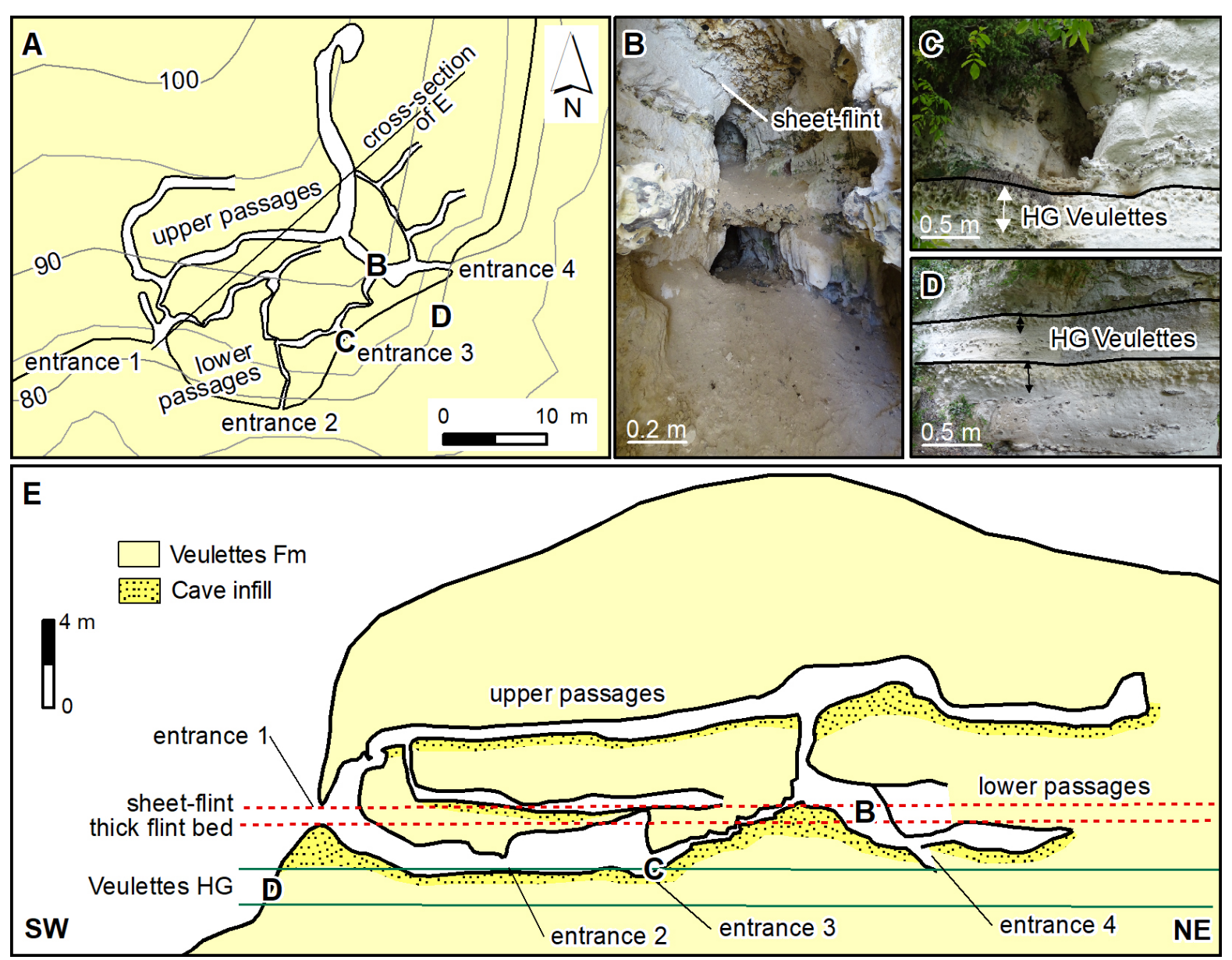

Fig. 6. A) Plan view of Roche Foulon Cave plotted on the geological map. Cave position is shown in Fig. 1D; B) Main gallery of the cavity influenced by a sheet-flint and the Veulettes hardgrounds, which are covered by sediments on the bottom of the gallery; C) Entrance 3 of the cave developed above the upper Veulettes hardground (their tops are displayed by a line);

D) Veulettes hardgrounds identified in the cliff adjacent to the entrance; E) Geological profile of Roche Foulon Cave whose lower passages were developed along Veulettes hardgrounds, a thin flint bed and a sheet-flint.

\section{Roche Percée Cave}

The Roche Percée Cave (49¹5'20.9”N, 1²1'55.3”E), is located on the north side of the Les Andelys meander $30 \mathrm{~km}$ southeast of Rouen. The cave is situated at the top of a rocky bluff above the Seine River and is $480 \mathrm{~m}$ long. It comprises a horizontal labyrinthine network of phreatic/epiphreatic passages partially filled with silt, sand, clay and flint nodules, and vadose canyons (Fig. 7A). Two vertical shafts developed along a minor fault represent sediment-filled dissolution pipes. The over 300 m-long network of small labyrinthine galleries converges on a main phreatic/epiphreatic conduit of $125 \mathrm{~m}$ long, drained to the south.

The cave was formed within yellowish to white bioclastic packstone chalk in the upper part of the Veullettes Fm (Fig. 7A). The main phreatic/epiphreatic conduits were formed between two hardgrounds, which can be correlated with the Veulettes hardgrounds on the coast. The small labyrinthine phreatic/epiphreatic passages are mainly developed on the lower of the two hardgrounds, with $1 \mathrm{~m}$ of separation (Fig. 7B-D). The vadose canyons in the northern end of the cave cut down into the underlying chalk along a fracture, with marked steps related to the occurrence of sheet-flints.

\section{Mont-Pivin cave system}

The Mont-Pivin cave system is located on the north side of the Les Andelys meander $30 \mathrm{~km}$ southeast of
Rouen, $2.7 \mathrm{~km}$ east-southeast of the Roche Percée cave (Fig. 1D). The Mont-Pivin cave system comprises two caves: the 1'Hôpital (49²1'51.30"N, 1'23'43.66"E) and St-Jacques caves (49 $\left.{ }^{\circ} 14^{\prime} 52.49 ” N, 1^{\circ} 23^{\prime} 37.88^{\prime \prime E}\right)$, together with several other smaller isolated cavities located at the same altitude (Fig. 8A). Prior to excavation, both caves were almost filled to the roof with sediment. They were connected together by excavating the cave deposits creating a single system with a combined length of $328 \mathrm{~m}$. Both caves are very close to the surface of the plateau and contain well-stratified clay, silt and sand deposits reworked from the overlying surface deposits including loess (Rodet et al., 2006). Vertical shafts filled with sediment are also present. Small flowstone formations are located along the cave wall and close to the cave ceiling.

This cave system comprises two phreatic conduits that have undergone subsequent paragenetic enlargement following the episodic influx of more than $4 \mathrm{~m}$ of detrital infill (Fig. 8B). In plan view, the cave has a branchwork pattern. The geometry of the conduit network and scallops indicate flow to the northwest. The stratigraphical position of the MontPivin cave system is the same as the Rouche Foulon, Trou d'Enfer and Roche Percée caves. The Mont-Pivin cave system initiated on the Veulettes hardgrounds (Fig. 8C), and then evolved upwards under paragenetic conditions. 


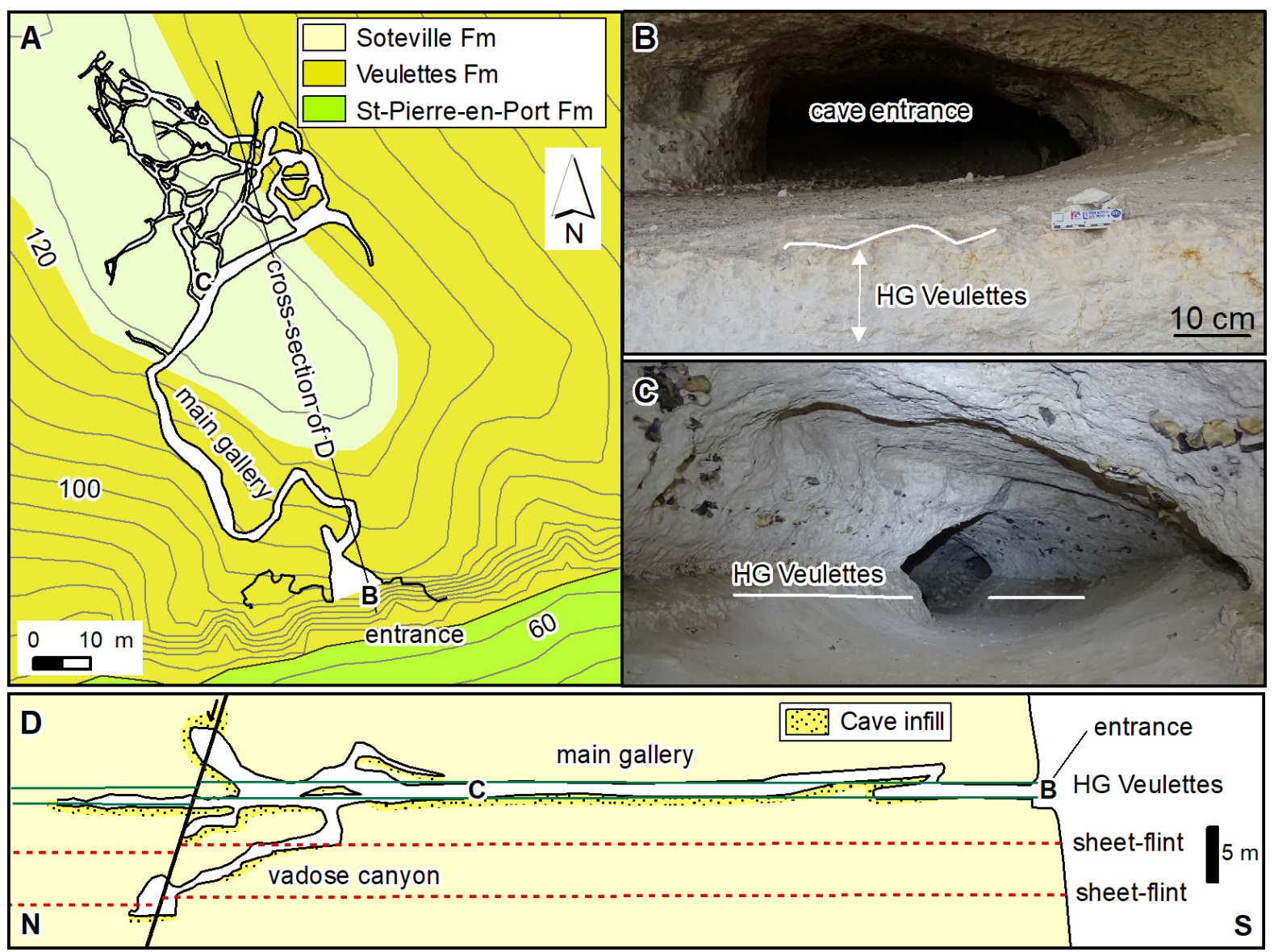

Fig. 7. A) Plan view of Roche Percée Cave plotted on the geological map. Cave position is displayed in Fig. 1D; B) Cave entrance developed on the lower Veulettes hardground (its top is represented by a line); C) Main gallery following the Veulettes hardgrounds; D) Geological section of Roche Percée Cave developed following the lower Veulettes hardground and two sheet-flints that influenced the development of a vadose canyon. A normal fault with $0.2 \mathrm{~m}$-vertical displacement is associated with a shaft infilled with Clay-with-Flints.
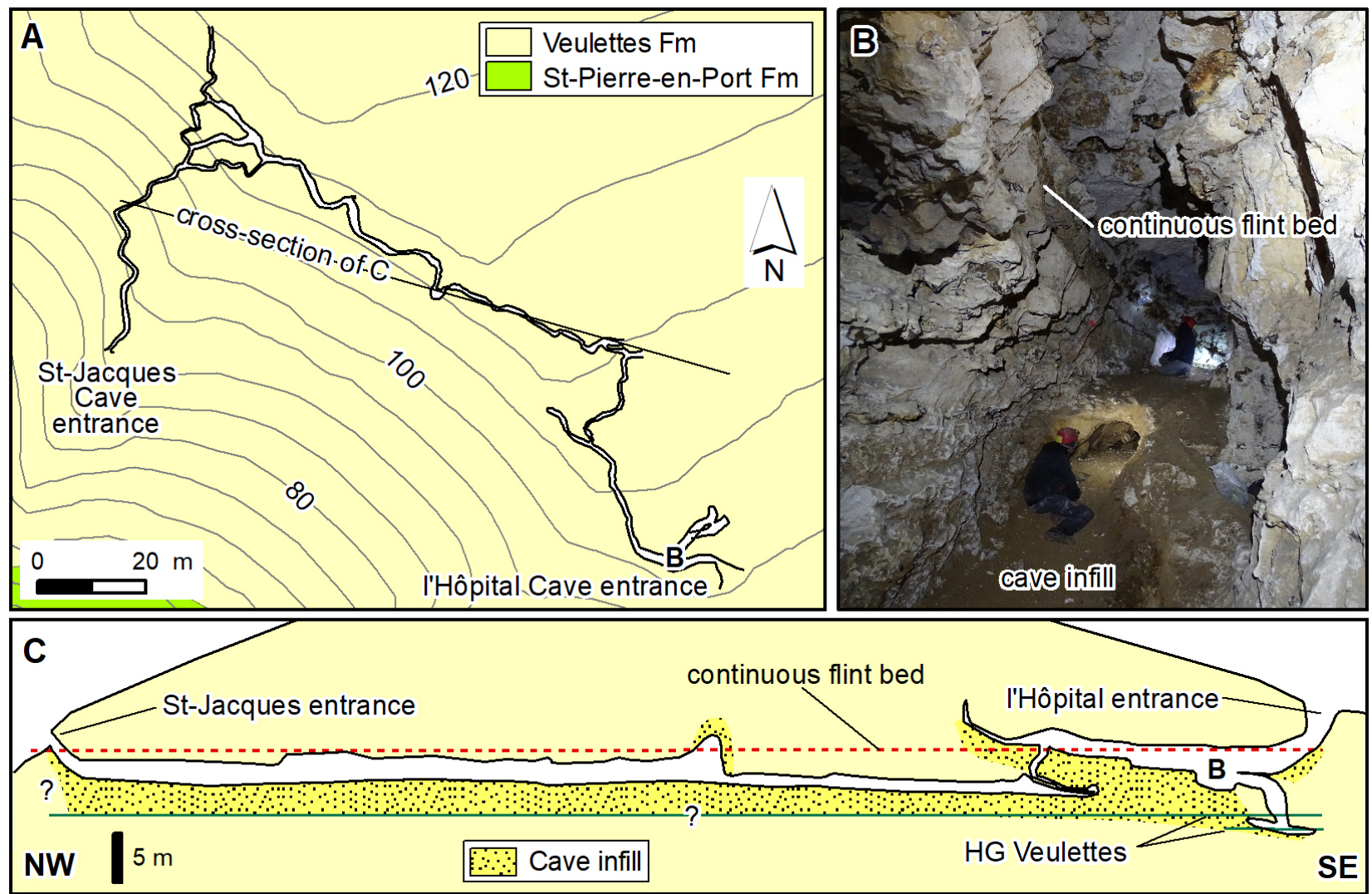

Fig. 8. A) Plan view of Mont-Pivin cave system (St-Jacques and l'Hôpital caves), the location of which is indicated in Fig. 1D; B) Main gallery influenced by a flint band and partially filled by detrital sediments; C) Geological section of Mont-Pivin cave system, the cave initiated on the Veulettes hardgrounds (the top of which is indicated by a line) and enlarged upwards by paragenesis. The hardgrounds are recognised in the southeast part of the cave. 


\section{Cave morphometric analyses}

Table 2 shows the values of the 14 morphometric parameters calculated from cave survey data in order to quantify the cave geometry. The length (Lr) of the caves varies from 76 to $4164 \mathrm{~m}$, whilst the cave area (Ac) ranges between 132 to $11,059 \mathrm{~m}^{2}$. The cave volume (Vc) is also very variable, ranging from 200 to $32,728 \mathrm{~m}^{3}$. For most caves, the calculated volume is an underestimate of the true value because of the presence of significant volumes of cave infill (Nehme et al., 2020), which have been partially excavated to enable exploration. These factors distort also the values of the asymmetry ratio, specific volume and cave porosity. Asymmetry ratios $(R=$ quotient of horizontal and vertical diameters) are generally >1 indicating low flat conduits rather than tall narrow ones. The exceptions are the Funiculaire Cave, whose conduits show rounded sections $(\mathrm{R}=0.99)$ typical of phreatic/epiphreatic systems, and the Mont-Pivin cave system, where the conduit sections are more canyon-like in form $(\mathrm{R}=0.38)$. In the latter case, the influx of sediment has caused the upward erosion of the passage, creating a paragenetic canyon. The specific volume ( $\mathrm{SV}=$ cave volume/cave real length) is low (1.17-4.80 $\left.\mathrm{m}^{3} \mathrm{~m}^{-1}\right)$ suggesting a low degree of karstification. However, the Caumont cave system has the highest specific volume $\left(\mathrm{SV}=7.86 \mathrm{~m}^{3} \mathrm{~m}^{-1}\right)$ of the studied caves indicating greater cave development and karstification, possibly due to the local dedolomitization of the chalk bedrock (Ballesteros et al., 2021). This process caused a reduction in rock primary porosity, significantly changing the hydrogeological properties of the chalk (Nader et al., 2013), making the dedolomitized chalk petrologically more similar to common karstified limestones.

The cave porosity values $(\mathrm{Pc}=$ cave volume/cave $3 \mathrm{D}$ cuboid volume) for the Roche Perceee, Funiculaire, Six Frères and Roche Foulon caves $(\mathrm{Pc}=1.4-3.1 \%)$ are larger than $1 \%$ because they are mainly maze caves, whilst the Caumont and Mont-Pivin cave systems have branchwork patterns with cave porosities of $0.1-0.4 \%$. The values of passage density $\left(\mathrm{PD}=0.14-0.21 \mathrm{~m} \mathrm{~m}^{-2}\right)$ and areal coverage $\left(\mathrm{AC}=13.73-37.88 \mathrm{~m}^{2} \mathrm{~m}^{-2}\right)$ of the caves (except for the Caumont cave system) coincide with the mean values $\left(\mathrm{PD}=\sim 0.17 \mathrm{~m} \mathrm{~m}^{-2}\right.$ and $\mathrm{AC}=$ $\sim 29.7 \mathrm{~m}^{2} \mathrm{~m}^{-2}$ ) suggested for maze caves by Klimchouk (2006), reflecting the development of paragenetic anastomotic networks and, in the case of Mont-Pivin cave system, the formation of a paragenetic canyon. The Caumont cave system presents a passage density of $0.02 \mathrm{~m} \mathrm{~m}^{-2}$ and an areal coverage of $6.06 \mathrm{~m}^{2} \mathrm{~m}^{-2}$, values more typical of conduit development within common limestone and unconfined settings $(\mathrm{PD}=$ $\sim 0.02 \mathrm{~m} \mathrm{~m}^{-2}$ and $\mathrm{AC}=\sim 6.4 \mathrm{~m}^{2} \mathrm{~m}^{-2}$, Klimchouk, 2006).

The Vertical Index and Horizontal Index values (0.010.16 and 0.89-0.99 respectively) are characteristic of horizontal phreatic cave systems within low gradient settings. The complex horizontal indexes (1.71-5.30) are lower than typical values for common caves, including maze caves (Piccini, 2011). This probably reflects the less karstified nature of the Chalk compared to other limestone areas.

Table 2. Morphometric parameters of the six study caves ordered from largest to smallest real length. Calculation methods are detailed in Table 1.

\begin{tabular}{|l|c|c|c|c|c|c|c|}
\hline \multicolumn{1}{|c|}{ Parameter/Index } & Unit & $\begin{array}{c}\text { Caumont } \\
\text { cave system }\end{array}$ & $\begin{array}{c}\text { Roche } \\
\text { Percée Cave }\end{array}$ & $\begin{array}{c}\text { Funiculaire } \\
\text { Cave }\end{array}$ & $\begin{array}{c}\text { Mont-Pivin } \\
\text { cave system }\end{array}$ & $\begin{array}{c}\text { Roche } \\
\text { Foulon Cave }\end{array}$ & $\begin{array}{c}\text { Six Frères } \\
\text { Cave }\end{array}$ \\
\hline Real length (Lr) & $\mathrm{m}$ & 4164 & 571 & 406 & 328 & 170 & 76 \\
\hline Plan length (Lp) & $\mathrm{m}$ & 3685 & 556 & 403 & 321 & 162 & 71 \\
\hline Vertical range (VR) & $\mathrm{m}$ & 60 & 18 & 4 & 11 & 9 & 13 \\
\hline Cave area (Ac) & $\mathrm{m}^{2}$ & 11059 & 593 & 365 & 325 & 132 & 205 \\
\hline Cave volume (Vc) & $\mathrm{m}^{3}$ & 32728 & 1260 & 483 & 629 & 200 & 365 \\
\hline Asymmetry ratio (R) & - & 1.52 & 1.24 & 0.99 & 0.68 & 1.16 & 2.27 \\
\hline Specific volume (SV) & $\mathrm{m}^{3} / \mathrm{m}$ & 7.86 & 2.21 & 1.19 & 1.92 & 1.17 & 4.80 \\
\hline Passage density (PD) & $\mathrm{m}^{\prime} \mathrm{m}^{2}$ & 0.02 & 0.21 & 0.15 & 0.19 & 0.20 & 0.14 \\
\hline Areal coverage (Ac) & $\mathrm{m}^{2} / \mathrm{m}^{2}$ & 6.06 & 21.84 & 13.73 & 18.59 & 15.28 & 37.88 \\
\hline Cave porosity (Pc) & $\%$ & 0.1 & 1.4 & 2.1 & 0.4 & 1.9 & 3.1 \\
\hline Vertical index (VI) & - & 0.01 & 0.03 & 0.01 & 0.03 & 0.05 & 0.16 \\
\hline Horizontal index (HI) & - & 0.89 & 0.97 & 0.99 & 0.98 & 0.95 & 0.94 \\
\hline Complex horizontal index (CHI) & - & 2.67 & 5.30 & 4.87 & 2.28 & 2.14 & 1.71 \\
\hline Linearity index (LI) & - & 0.35 & 0.23 & 0.22 & 0.48 & 0.52 & 0.80 \\
\hline
\end{tabular}

The sinuosity (or tortuosity) and anastomotic aspect indicated by the complex horizontal (CHI) and linearity indexes (LI) suggest cave development forced by the presence of hardgrounds (Fig. 9), despite the small sample size and other constraints of the morphometrical analyses. The Funiculaire and Roche Percée caves, developed between two regional and well-defined hardgrounds, have the highest complex horizontal index (4.87-5.3) values and lowest coefficients of linearity index (0.220.23). Their geometries are more horizontal, sinuous and labyrinthine than the other studied caves. The Mont-Pivin cave system and Rouche Foulon caves have moderate complex horizontal index (2.142.28) and linearity index (0.48-0.52) values (Fig. 9) since they are clearly developed under conditions of high sediment flux, with upward paragenetic cave development from the Veulettes hardgrounds. These values are similar to the indexes calculated for the Caumont cave system $(\mathrm{CHI}=2.67 ; \mathrm{LI}=0.35)$ suggesting a similar origin for the formation of this cavity. In those caves where there has been significant 
sediment influx, the bulk of the conduit is developed above the inception horizon, unlike the Funiculaire and Roche Percée caves, modifying the $\mathrm{CHI}$ and LI indices. Finally, the Six Frères cave is influenced by only one hardground and displays the lowest value of CHI (1.81) and highest coefficient of LI (0.75). The data suggests that chalk caves developed between/ or on hardgrounds have greater tortuosity values and are typically more horizontal than caves that develop above a hardground. This probably reflects the change in morphology which occurs when a cave undergoes subsequent paragenetic enlargement.

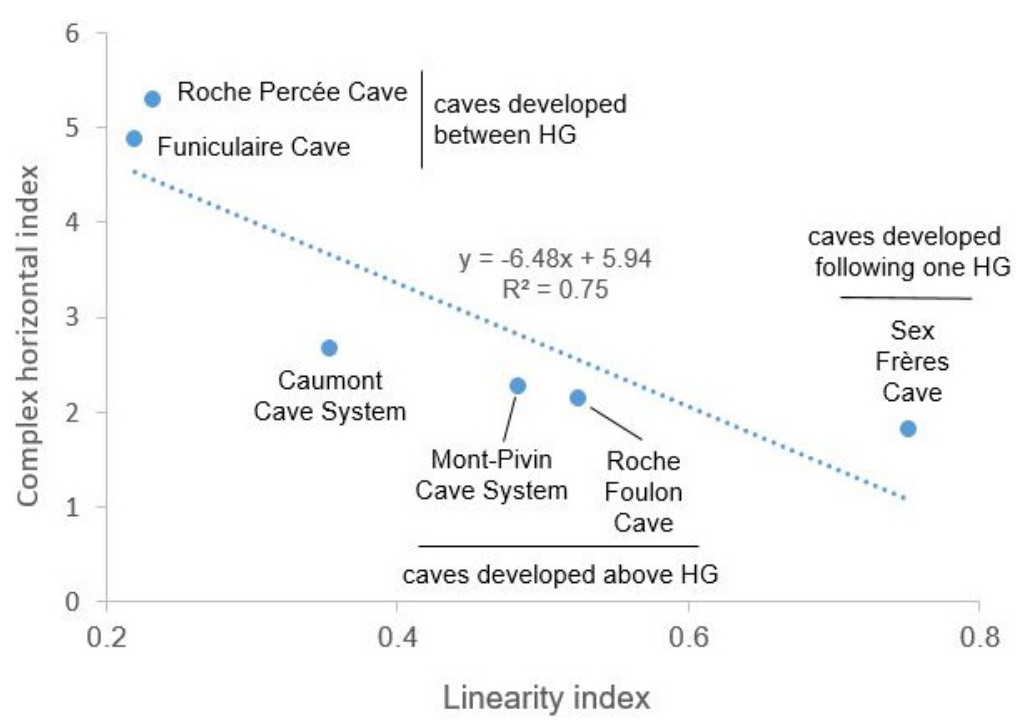

Fig. 9. Correlation of the Complex Horizontal Index $(\mathrm{CHI})$ vs. the Linearity Index (LI) of the studied caves (detailed in Table 2) showing a correlation coefficient $\left(R^{2}\right)$ of 0.75 . Three groups can be identified reflecting stratigraphical influence: caves developed between hardgrounds (Roche Percée and Funiculaire caves), paragenetic caves formed per ascensum above hardgrounds (Mont-Pivin cave system, Roche Foulon Cave, and probably the Caumont cave system), and caves developed along a hardground (Six Frères cave).

\section{Evidence from other caves and conduits in Normandy.}

Other significant chalk caves occur in the Normandy area. The $1.4 \mathrm{~km}$ long Petites-Dales cave near Fécamp on the Normandy coast (Fig. 10) consists of a subhorizontal main gallery with four tributary branches, some of which connect to vertical sediment-filled pipes (Chédeville et al., 2015). The main passage is a phreatic conduit 2-5 $\mathrm{m}$ diameter, which was infilled by $>10 \mathrm{~m}$ of detrital sediment partially excavated by speleologists. The bedrock stratigraphy exposed in the cave is similar to that seen in the Caumont cave system, with the Nostrils hardground and the Shoreham marls exposed in the main passage (Fig. 10), (Hoyez, 2013). The Epivent hardground, approximately $5 \mathrm{~m}$ lower, is exposed in the places where the sediment has been fully excavated. The passage morphology and extensive sediment fill indicate that much of the cave system initiated at the level of the Epivent hardground (locally lower) and enlarged upwards under paragenetic conditions (Chédeville et al., 2015).

In Normandy, the main karst springs are related to hardgrounds, marl seams and sheetflints within the Turonian to Coniacian chalk (Table 3). Gaillard et al. (2012) reported that karst springs located in the intertidal zone at Yport (Fig. 1B) discharge up from the Chicard Cape hardground, which is correlated with the Navigation hardground (Lewes Nodular Chalk) of southern England. The springs are fed by a well-developed karst conduit system with an extensive catchment covering more than $106 \mathrm{~km}^{2}$ (Gaillard et al., 2012). The springs are highly productive with rapid transfer through conduits. In Yport village, a 40-m-borehole intercepted a water filled karst conduit about $3 \mathrm{~m}$ in diameter associated with the Navigation hardground. This hardground is linked with other large karst springs along the Normandy Coast, including the Gouffre and Poule springs (Table 3; Fig. 1B). In the Seine River catchment, significant karst springs are associated to the Turonian Southerham marl and the Tilleul hardgrounds (e.g., the Funiculaire Cave; section 4.1.1). Some of these springs constitute major public water sources, including the Radicatel springs, which supply $\sim 50 \%$ of the potable water supply for the city of Le Havre (Fig. 1B). Tracer tests to the main karst springs indicate groundwater velocities of 200-300 m $\mathrm{h}^{-1}$ (Table 1) reinforcing the conceptualization of the chalk as a karstic aquifer.

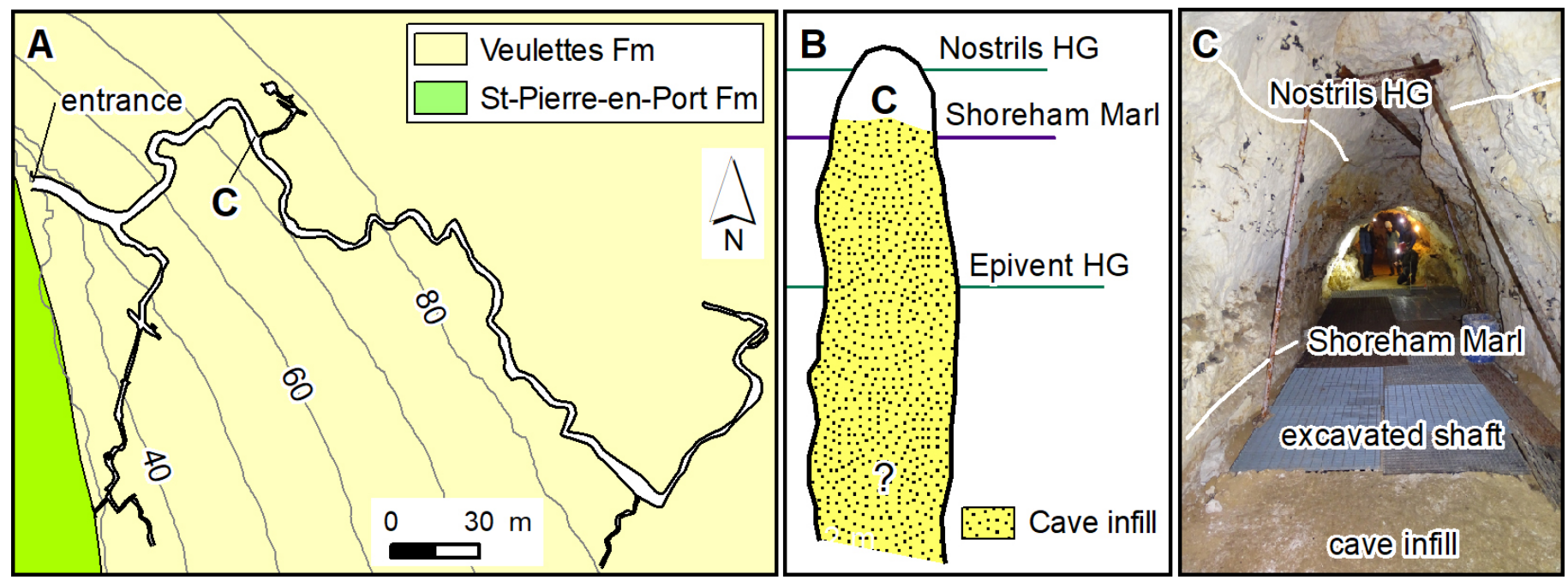

Fig. 10. A) Plan view of the Petites-Dales Cave (Rodet \& Viard, 2009) plotted on the geological map. The location is shown in Fig. 1B; B) Transverse section of the main gallery, largely infilled by detrital sediment, with the Nostrils hardground and Shoreham marl (Hoyez, 2013); C) Upper part of the main gallery showing the Nostrils HG and Shoreham Marl. The position of Petite Dales Cave in the stratigraphical section is shown in Fig. 3. 
Table 3. Karst springs with average discharges larger than $200 \mathrm{~L} \mathrm{~s}^{-1}$ during low water conditions and their associated stratigraphical layers. Discharges and groundwater velocities are inferred from dye tracing experiments published on a public platform (http://sigessn.brgm.fr/). The position of the springs is shown in Fig. 1B.

\begin{tabular}{|c|c|c|c|c|}
\hline Karst springs & $\begin{array}{c}\text { Discharges } \\
\left(L^{-1}\right)\end{array}$ & Geological formations & Stratigraphical layer & $\begin{array}{c}\text { Groundwater } \\
\text { velocities }\left(\mathbf{m ~ h} \mathbf{h}^{-1}\right)\end{array}$ \\
\hline Yport & $>2400$ & St-Pierre-en-Port & Navigation hardground & $238-290$ \\
\hline Moulin (Moulineaux) & 1500 & St-Pierre-en-Port & $\begin{array}{c}\text { Hope Gap sheet-flint } \\
\text { Epivent / Cliff hardground }\end{array}$ & $159-277$ \\
\hline La Forge (Bonneville-sur-Iton) & 1250 & $\begin{array}{l}\text { Rouen } \\
\text { Fécamp }\end{array}$ & Antifer hardgrounds & $169-310$ \\
\hline La Fontaine de Hondouville & 1180 & Senneville & Southerham marl (?) & $>90$ \\
\hline Gaudreville-la-Rivière & 1050 & $\begin{array}{c}\text { Rouen } \\
\text { Fécamp }\end{array}$ & Antifer hardgrounds & $180-290$ \\
\hline Radicatel (Tancarville) & $\sim 750$ & St-Pierre-en-Port & Navigation hardground & $224-700$ \\
\hline Val-St-Martin (Beaumont-le-Roger) & 1050 & $\begin{array}{c}\text { Senneville } \\
\text { Val-St-Nicolas }\end{array}$ & $\begin{array}{l}\text { Tilleul hardgrounds } \\
\text { Southerham marl }\end{array}$ & $199-244$ \\
\hline Bec-de-Mortagne & 550 & $\begin{array}{c}\text { Senneville } \\
\text { Val-St-Nicolas }\end{array}$ & Tilleul (?) hardgrounds & $\sim 250$ \\
\hline Les Cressonnieres (Cailly-sur-Eure) & $\sim 500$ & St-Pierre-en-Port & Senneville hardgrounds & $250-254$ \\
\hline Bernay West & $\sim 400$ & Fécamp & Antifer hardgrounds (?) & $223-300$ \\
\hline Roger (Beaumont-le-Roger) & 450 & Senneville & Southerham marl & $206-252$ \\
\hline Le Vivier de Valmont & 342 & $\begin{array}{c}\text { Senneville } \\
\text { Val-St-Nicolas }\end{array}$ & Tilleul hardgrounds (?) & $\mathrm{N} / \mathrm{A}$ \\
\hline Les Cressonnieres (Fontaine-sous-Préaux) & 390 & Senneville & Southerham marl (?) & $\sim 360$ \\
\hline Gouffre (Dieppe) & 250 & St-Pierre-en-Port & Lewes / Navigation marl & $\mathrm{N} / \mathrm{A}$ \\
\hline Poule (Melleville-sur-Mer) & $\sim 200$ & St-Pierre-en-Port & Lewes / Navigation marl & $\mathrm{N} / \mathrm{A}$ \\
\hline
\end{tabular}

The exceptional cliff sections along $>150 \mathrm{~km}$ of coastline between Le Havre and Le Tréport (Fig. 1B), expose numerous karst conduits and water sources related to marl beds and hardgrounds. At Le Tilleul beach, a perched phreatic conduit was developed on the Tilleul 2 hardground (Fig. 11A) while karst springs such as Les Pissuers de Valaine emerge from the cliff along the Southerham marl (Fig. 11B), which here forms a prominent dolomitised body (Hoyez, 2008). Sediment-filled conduits at the same level show clear evidence of upwards paragenetic development. Other short caves nearby are developed on the same hardground. Further to the south, minor springs (e.g., Les Pissuers La Place) emerge from the Antifer Marl at the base of the Fourquet cliff (Fig. 11C). This is an important regional karst inception horizon which forms a relative low permeability horizon associated with a prominent spring line on the coast. At Senneville and Etretat, springs are developed on marl seams in the lower part of the Val-St-Nicolas (New Pit Chalk) Formation. (Fig. 11D-F), as well as many karst conduits originated on hardgrounds (Fig. 11G). Further north at Dieppe, the prominent semi-tabular Seven Sisters flint band (lower Seaford Chalk Fm) forms a well-developed inception horizon with many sediment filled conduits developed along its upper surface (Fig. 11H).

\section{Evidence from caves and conduits in southern England.}

In southern England, cave systems are not as well developed, with few known enterable caves, although karst features such as stream sinks, dissolution pipes and large springs are common. Evidence from coastal sections in Sussex and Kent indicate that conduit systems usually occur at certain stratigraphical levels, most typically on marl seams and sheet flints. Hardgrounds are fewer and less well developed in the more basinal Chalk sequence and tend to be concentrated in the Lewes Nodular Chalk (equivalent to the St Pierre-en-Port Fm) and Holywell Nodular Chalk formations (Fig. 2, Mortimore, 2019; Gale, 2019).

In Sussex, over 60 conduits have been identified on the coast between Seaford Head and Eastbourne (Fig. 1A). All are developed on sheet flints or marl seams, notably the Belle Tout marls in the lower Seaford Chalk, the Shoreham and Navigation marls in the upper Lewes Nodular Chalk, and the Hope Gap sheet flint (Fig. 12). They are typically associated with a zone of tubule karst up to $0.5 \mathrm{~m}$ thick above the inception horizon (Fig. 12B) (LamontBlack \& Mortimore, 2000). The largest is the $400 \mathrm{~m}$ long Beachy Head Cave (Waltham et al., 1997) near Eastbourne, a small relict quasi-horizontal phreatic branchwork system developed on a localised sheetflint in the upper part of the Lewes Nodular Chalk Fm. At Seaford Head, many small relict phreatic caves and conduits occur along a sheet-flint immediately above the Hope Gap hardground (Fig. 12D), some with subsequent vadose incision. Conduits are rare in the middle and upper Seaford Chalk Formation, where marl seams, hardgrounds and sheet flints are absent. At St Margaret's Bay in Kent, north of Dover, the 120-m long Canterbury Cave is a small relict phreatic conduit developed on a sheet-flint in the upper part of the Lewes Nodular Chalk Fm. Many other smaller conduits occur at this level in the cliffs nearby (Fig. 12A). Elsewhere in Kent, a sediment filled conduit $3 \mathrm{~m}$ wide, up to $4 \mathrm{~m}$ high and $40 \mathrm{~m}$ long was discovered in 1879 during construction of a water adit deep beneath Strood Waterworks, near Chatham (Fig. 1B). This cave is also developed on a sheet-flint in the upper Lewes Nodular Chalk Fm. 

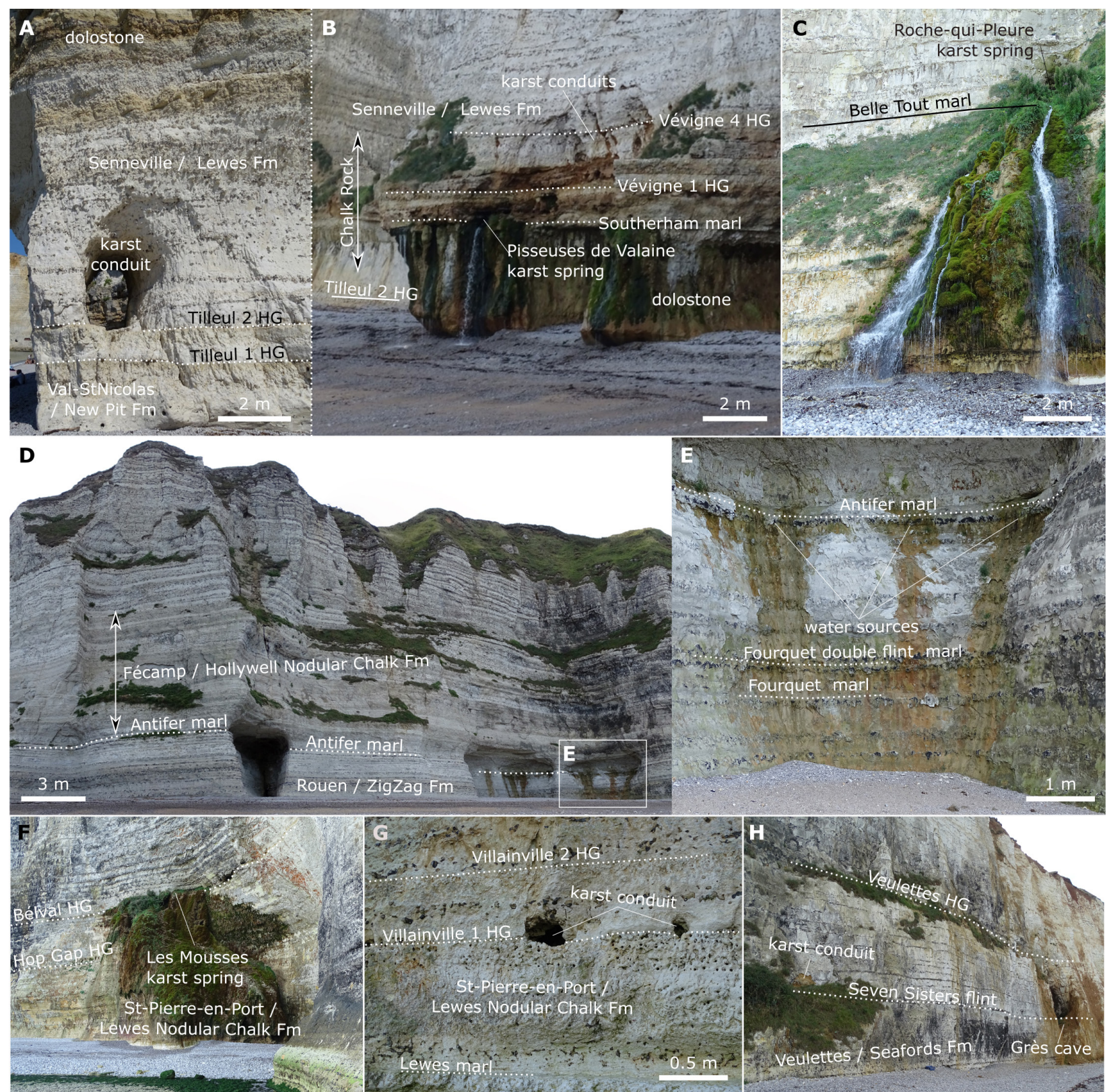

Fig.11. A) Karst conduit developed on middle Turonian Tilleul 2 hardground at Le Tilleul beach; B) Pisseuses de Valaine karst spring (500 north Le Tilleul Beach) emerging at the upper Turonian Southerham marl; C) Roche-qui-Pleure spring associated with the Belle Tout marl 2 at Grainval; D and E) Upper Cenomanian Antifer Marl related to minor water sources at Fourquet beach; F) Les Mousses spring associated with Bélval HG at Etretat; G) Karst conduits developed on the upper Turonian Villainville hardground at Etretat; H) Grès cave and minor sediment-filled karst conduit following middle Coniacian Seven Sisters semi-tabular flint at Veulettes-lesRoses. Stratigraphical interpretations after Kennedy \& Juignet (1974) and Hoyez (2008). The top of the hardgrounds is highlighted in the pictures. The position of the locations is shown in Fig. 1B.

\section{DISCUSSION}

\section{Role of sheet-flints and hardgrounds on conduit development}

The combination of robust cave surveys and a detailed stratigraphical framework enables the proportion of cave passage (cave real length) that is developed along a certain stratigraphical horizon (Table 4) to be calculated. The greatest density of cave passages corresponds to the part of the Chalk sequence with the highest concentration of hardgrounds; the St-Pierreen-Port Formation (Lewes Nodular Chalk) (Fig. 2). In the overlying Veulettes Fm (Seaford Chalk Fm), all the Normandy caves are associated with hardgrounds, despite them being relatively scarce in this part of the succession. Additional evidence can be gained from identifying the stratigraphical elevation of springs and other karstic features exposed along the Seine Valley, on the Normandy coast and in southern England. The data collected from the studied caves and coastal sections is used to identify the key stratigraphical inception horizons that guide groundwater flow in the aquifer.

In our study, $\sim 68 \%$ of the passage length in the studied caves were influenced by the middle Turonian Le Tilleul hardgrounds located at the top of Val-StNicolas Fm, the lower Coniacian Epivent and Bocage hardgrounds at the top of the St-Pierre-en-Port Fm, and the upper Coniacian Veulettes hardgrounds within the Veulettes Fm (Table 4). The Tilleul and Epivent hardgrounds are basin scale features than can be recognised across northern France, whilst other hardgrounds are more localised regional-scale horizons (Hoyez, 2008). 

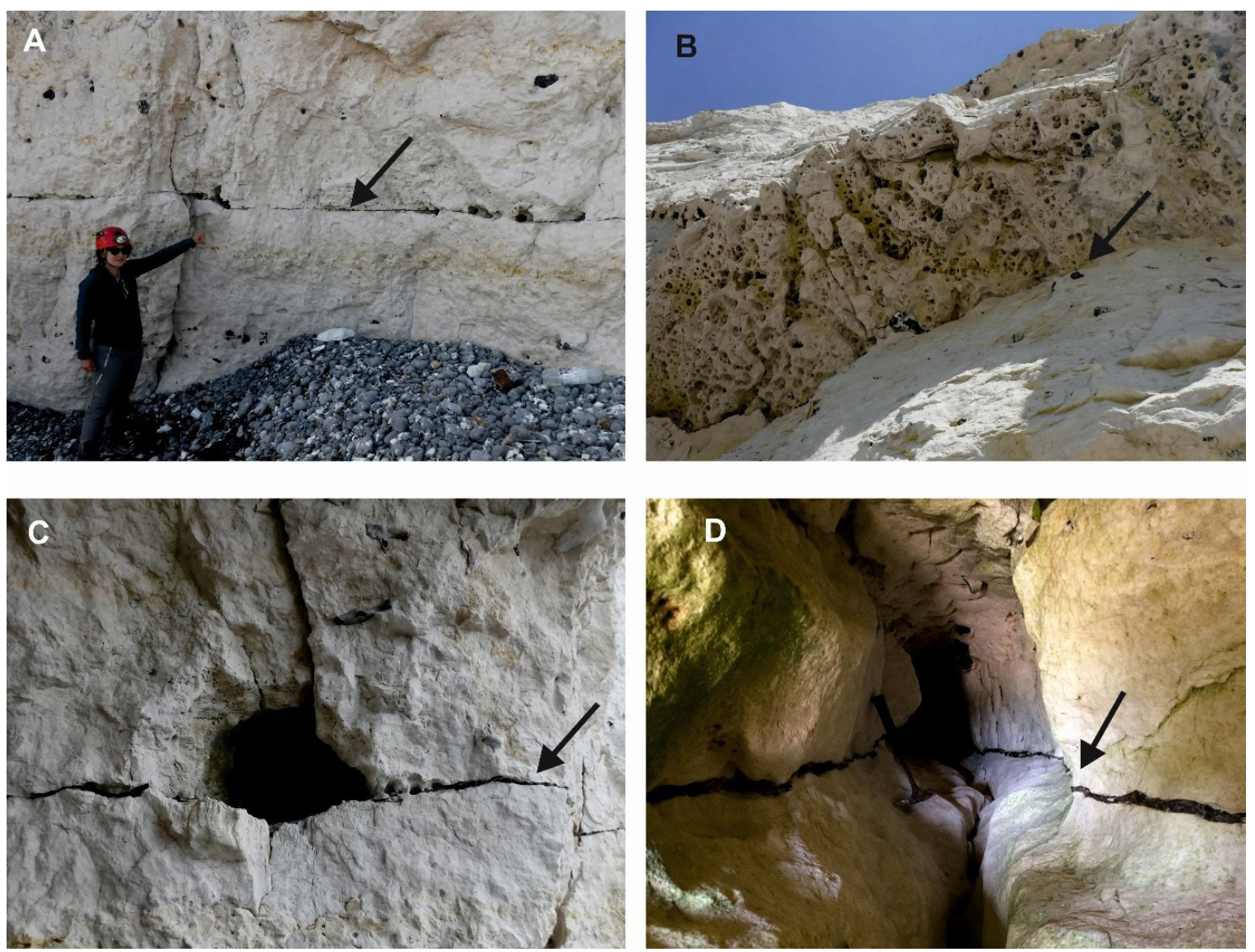

Fig. 12. Dissolutional conduits formed by mixing dissolution above a sheet flint (arrowed). A) St Margaret's Bay, Kent; B) Detail looking up at the underside of a bedding surface (the sheet flint has fallen away) showing a conduit network embedded in a mesh of small dissolutional voids ('tubule karst' of Lamont-Black \& Mortimore, 2000), Beachy Head,

Sussex; C) St Margaret's Bay, Kent; D) Hope Gap, Seaford Head, Sussex.

Table 4. Length and percentage of phreatic/epiphreatic study cave conduits forced by hardground and flint beds. $22 \%$ of studied cave conduits are vadose or phreatic/epiphreatic passages not influenced by any identified stratigraphical horizons.

\begin{tabular}{|c|c|c|c|c|c|}
\hline \multirow{3}{*}{ Funiculaire } & Cave real length (m) & Sheet-fl & nt beds & & \\
\hline & \multirow{2}{*}{405} & \multirow{2}{*}{\multicolumn{2}{|c|}{-}} & \multicolumn{2}{|c|}{ Tilleul hardgrounds } \\
\hline & & & & $65 \mathrm{~m}$ & $16 \%$ \\
\hline \multirow{2}{*}{ Caumont } & \multirow{2}{*}{4164} & \multicolumn{2}{|c|}{ Hope Gap sheet-flint } & \multicolumn{2}{|c|}{ Etigue, Epivent and Bocage hardgrounds } \\
\hline & & $505 \mathrm{~m}$ & $12 \%$ & $2941 \mathrm{~m}$ & $71 \%$ \\
\hline \multirow{2}{*}{ Six Frères } & \multirow{2}{*}{76} & \multicolumn{2}{|c|}{ Ectot tabular flint beds } & \multicolumn{2}{|c|}{ Veulettes hardgrounds } \\
\hline & & $59 \mathrm{~m}$ & $78 \%$ & $17 \mathrm{~m}$ & $22 \%$ \\
\hline \multirow{2}{*}{ Roche Foulon } & \multirow{2}{*}{172} & \multirow{2}{*}{\multicolumn{2}{|c|}{-}} & \multicolumn{2}{|c|}{ Veulettes hardgrounds } \\
\hline & & & & $97 \mathrm{~m}$ & $56 \%$ \\
\hline \multirow{2}{*}{ Grotte Percée } & \multirow{2}{*}{439} & \multirow{2}{*}{\multicolumn{2}{|c|}{-}} & \multicolumn{2}{|c|}{ Veulettes hardgrounds } \\
\hline & & & & $395 \mathrm{~m}$ & $90 \%$ \\
\hline \multirow{2}{*}{ Mont-Pivin } & \multirow{2}{*}{328} & \multirow{2}{*}{\multicolumn{2}{|c|}{-}} & \multicolumn{2}{|c|}{ Veulettes hardgrounds } \\
\hline & & & & $301 \mathrm{~m}$ & $92 \%$ \\
\hline TOTAL & 5584 & $564 \mathrm{~m}$ & $10 \%$ & $3816 \mathrm{~m}$ & $68 \%$ \\
\hline
\end{tabular}

Sheet and semi-tabular flint bands influence the development of $\sim 10 \%(0.6 \mathrm{~km})$ of the studied phreatic/ epiphreatic passage in the Normandy caves (Table 4). Of these, the sheet-flint correlated with that observed at Hope Gap in Sussex (Mortimore, 2019) is the most significant as it influences conduit development in parts of Caumont cave system (section 4.1.1) and at Seaford Head in Sussex. Other sheet-flint and flint beds recognised in Six Frères, Roche Foulon, Roche Percee and the Mont-Pivin systems played a secondary role in the development of the cave. Finally, the remaining $22 \%$ of study cave conduits detailed in Table 4 do not appear to be related to any identifiable stratigraphical horizon.
The evidence from coastal sections tells a similar story. The vast majority of known caves, conduits and springs on the Normandy coast are associated with either hardgrounds, sheet flints or marl seams. Sheet-flints influence the development of the majority of the known chalk cave systems in southeast England (Beachy Head Cave, the Hope Gap caves, Strood Waterworks Cave, and Canterbury Cave). Many of the caves and conduits in southern England are embedded within a well-developed, up to $0.5 \mathrm{~m}$ thick zone of enhanced dissolutional porosity formed by mixing corrosion (the tubule karst of LamontBlack \& Mortimore, 2000) just above a sheet-flint or hardground (Fig. 12D). It is characterised by 
a honeycombed network of small anastomosing conduits and isolated vuggy porosity within which larger conduits are embedded. The extensive nature of this high porosity zone which can extend for many hundreds of metres along suitable inception horizons suggests that lateral flow and mixing dissolution play a major role in conduit development. The coastal surveys demonstrate that where hardgrounds, sheet flints or marl seams are absent, karstic conduits are also rare or absent.

The density of conduits and caves is greater in Normandy because the basin margin setting of the Chalk Group favoured the development of numerous hardgrounds, sheet and semi-tabular flints (Mortimore, 2011, 2019), more so than in the more basinal setting in southern England. Moreover, the Cainozoic and Quaternary cover is thicker and more extensive, focusing more point recharge to the underlying Chalk.

\section{Speleogenesis along inception horizons}

In the Chalk, most groundwater flow occurs along solutionally enlarged fractures and discontinuities (Descamps et al., 2017; Hakoun et al., 2017), rather than via the matrix. The high matrix porosity causes any influent water to tend towards saturation very quickly compared to other less porous carbonate aquifers (Price et al., 2000). In addition, the fracture density of the Chalk offers the potential for many alternative flow-paths, enabling dissolution to be dispersed along many fractures and within the matrix. These two factors slow the rate of conduit development and inhibit the development of large conduit systems within geomorphically relevant timescales. The exception is where stratigraphical discontinuities such as sheet-flints, marl seams and hardgrounds serve to concentrate flow and enhance conduit development through mixing dissolution.

The permeability barriers presented by hardgrounds, sheet flints and marl seams promote lateral flow along the top of the inception horizon (e.g., Fig. 11G). Water descending down fractures (Fig. 13) meets the low permeability zone and flows laterally, allowing waters of different chemical composition to mix, causing additional dissolution and triggering the formation of karst protoconduits (Lowe \& Gunn, 1995; Lowe, 2000). If conditions are favourable for continued dissolution over sufficient periods of time, branchwork or maze systems will develop, depending of the aquifer recharge (Palmer, 1991), eventually enlarging into an accessible cave. Once a conduit has developed, it can be modified either by vadose incision, or by upwards paragenetic enlargement (Fig. 1). The spatial and vertical distribution of the inception horizons also influence passage geometry. Where inception horizons are widely spaced, conduits that initiate through mixing dissolution along the top of the hardground, sheet flint or marl seam may enlarge to create a phreatic or epiphreatic branchwork conduit, which can be up to $2 \mathrm{~m}$ in diameter (Fig. 13). Subsequent detrital sedimentary aggradation and paragenetic enlargement can modify the original cave geometry (Nehme et al., 2020). This is the case in the Six Frères, Roche Foulon and Mont-Pivin caves.

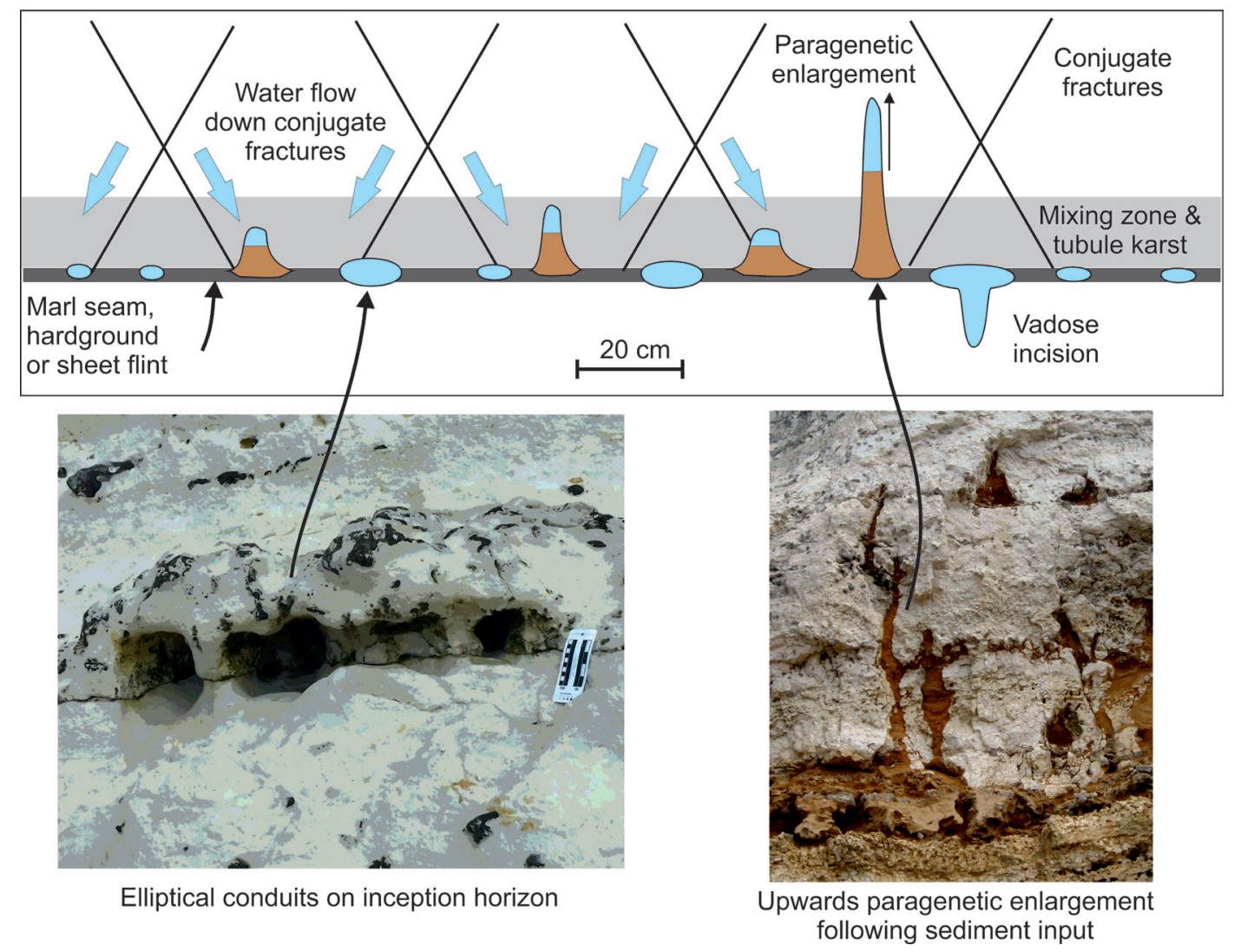

Fig. 13. Conceptual model of chalk cave genesis associated with hardgrounds, sheet flints and marl seams. Groundwater flow seeping down conjugate fractures meets a low permeability barrier and flows laterally. Mixing zone dissolution above the barrier forms small-scale elliptical conduits on the inception horizon. The conduits can be subsequently modified by vadose incision or if sediment is entrained in the system, the conduits may enlarge upwards by paragenesis. 
Where inception horizons are closely spaced (Fig. 13), more complex 3D mazes can develop as flow can converge and diverge on multiple horizons, especially during paragenetic development, resulting in the maze pattern exhibited by Funiculaire and Roche Percée caves.

\section{Implications for Chalk hydrogeology}

The study reinforces the concept that the chalk aquifer is heterogeneous and should be treated as a karst aquifer (e.g., El Janyani et al., 2014; Valdes et al., 2014; Chédeville et al., 2015; Delbart et al., 2016; Grube et al., 2017 and Brenner et al., 2018). The evidence from our study indicates that conduit development in the Chalk is often guided by hardgrounds, sheet/semi-tabular flint bands and marl seams (section 5.1). Most groundwater models do not currently consider karst development in the Chalk or single out preferential flow horizons, preferring to treat the chalk as a homogenous single porous medium. The identification of key stratigraphical horizons that are potential for conduit development may help in understanding groundwater flow pathways and high transmissivity zones within the aquifer. Combining the identification of key stratigraphical horizons with high resolution 3D geological models to determine the geometry of these flow horizons may lead to the development of more robust and accurate groundwater models.

\section{CONCLUSIONS}

The combination of geomorphological and morphometric analyses of Chalk caves and highresolution stratigraphical analysis of the host bedrock is used to define the role of lithological discontinuities on conduit development in the Chalk aquifer. In the Seine Valley and along the Normandy coast, prominent Turonian, Coniacian and Santonian hardgrounds have influenced the genesis of $68 \%(5.5 \mathrm{~km})$ of studied conduits, with sheet-flints and marl seams also playing a role, especially in southern England. This strong stratigraphical influence has favoured the development of sinuous and anastomosing conduit networks along these discontinuities. Branchwork conduit systems will develop where groundwater flow is concentrated above a hardground or sheet-flint. Where the conduits are sufficiently large and wellconnected to transmit surface-derived sediments, paragenetic cave development will occur, with conduits enlarging upwards (per ascensum) over a sediment fill, unless terminated by a hardground or sheet-flint.

The evidence presented here reinforces the visualization of the Chalk Group as a karst aquifer where groundwater flow and the aquifer discharge are strongly influenced by conduit development along hardgrounds, marl seams, sheet-flints and semi-tabular flint bands, which act as permeability barriers. The spatial and temporal distribution of these lithostratigraphical discontinuities is linked to their location within the Anglo-Paris basin. Synsedimentary slumping and depositional hiatuses that lead to the formation of hardgrounds and sheet-flints are more common at the basin margins. This favours the development of conduit systems within the Chalk succession. The relative lack of such features within the thick basinal successions of south-eastern England (Sussex and Kent) combined with less conducive geomorphological settings may explain the paucity of large cave systems in this area compared to the Seine Valley and Pays de Caux. Understanding the geometry, spatial and stratigraphical distribution of these lithostratigraphical discontinuities in a 3D geological model is an essential pre-requisite to developing more accurate hydrogeological models in the future.

\section{ACKNOWLEDGEMENTS}

We thank the Bureau de Recherches Géologiques et Minières (BRGM), especially B. Meire, for providing the geological maps, and B. Hoyez for his help in understanding the Chalk stratigraphy of the Seine Valley. We are also grateful to P. Rabelle (Comité Régional de Spéléologie de Normandie) and J.C. Staigre (Centre Normand d'Etude du Karst) for providing data on the cave systems. A.R. Farrant and M. Woods publish with the approval of the Executive Director, the British Geological Survey. We appreciate the effort of three anonymous reviewers, which revisions allowed us to improve the work.

Authorship Statement: AF conceived the original idea and directed the study with CN. CN, DM and DT carried out funding acquisition and project administration. DB mapped the study caves, established the bedrock stratigraphy and the structural control. DB performed morphometric analyses while $\mathrm{AF}$ and MW provided the studied cases in England. DB, AF and CN wrote the article, contributing all author to the discussion.

\section{REFERENCES}

Allen, D.J., Brewerton, L.J., Coleby, L.M., Gibbs, B.R., Lewis, M.A., MacDonald, A.M., Wagstaff, S.J., Williams, A.T., 1997. The physical properties of major aquifers in England and Wales. British Geological Survey Technical Report WD/97/34, Notting-ham, UK, 312 p. Antoine, P., Coutard, S., Guerin, G., Deschodt, L., Goval, E., Locht, J.L., Paris, C., 2016. Upper Pleistocene loess-palaeosol records from Northern France in the European context: Environmental background and dating of the Middle Palaeolithic. Quaternary International, 411, 4-24. https://doi.org/10.1016/j.quaint.2015.11.036

Arbonnier, G., Equilbey, E., Hanot, F., Mardhel, V., Pointet, T., Quesnel, F., Robelin, C., Schomburgk, S., Tourlière, B., 2004. Atlas hydrogéologique numérique de l'Eure. Volet Cartographie de l'aquifère de la craie. Rapport BRGM/RP-52989-FR, 90 p.

Azeez, N., West, L.J., Bottrell, S.H., 2015. Numerical simulation of spring hydrograph recession curves for evaluating behavior of the East Yorkshire chalk aquifer. In: Doctor, D.H., Land, L., Stephenson, J.B. (Eds.), Proceedings of the $14^{\text {th }}$ Sinkhole Conference. National Cave and Karst Research Institute, Rochester, p. 521530. https://doi.org/10.5038/9780991000951.1029 
Ballesteros, D., Jiménez-Sánchez, M., Giralt, S., GarcíaSansegundo, J., Meléndez-Asensio, M., 2015. A multimethod approach for speleogenetic research on alpine karst caves. Torca La Texa shaft, Picos de Europa (Spain). Geomorphology, 247, 35-54.

https://doi.org/10.1016/j.geomorph.2015.02.026

Ballesteros, D., Giralt, S., García-Sansegundo, J., Jiménez-Sánchez, M., 2019. Quaternary regional evolution based on karst cave geomorphology in Picos de Europa (Atlantic Margin of the Iberian Peninsula). Geomorphology, 336, 133-151.

https://doi.org/10.1016/j.geomorph.2019.04.002

Ballesteros, D., Painchault, A., Nehme, C., Todisco, D., Varano, M., Mouralis, D. 2021. Normand chalkstone (France): geology and historical uses from quarries to monuments. Episodes, 44, 1.

Barhoum, S., Valdès, D., Guérin, R., Marlin, C., Vitale, Q., Benmamar, J., Gombert, P., 2014. Spatial heterogeneity of high-resolution Chalk groundwater geochemistry - Underground quarry at Saint Martinle-Noeud, France. Journal of Hydrology, 519, 756-768. https://doi.org/10.1016/j.jhydrol.2014.08.001

Bloomfield, J.P., Marchant, B.P., Survey, G., Building, M., Gifford, C., Survey, G., Centre, E.S., 2013. Analysis of groundwater drought building on the standardised precipitation index approach. Hydrology and Earth System Sciences, 17, 4769-4787. https://doi.org/10.5194/hess-17-4769-2013

Brenner, S., Coxon, G., Howden, J.K., Freer, J., Hartmann, A., 2018. Process-based modelling to evaluate simulated groundwater levels and frequencies in a Chalk catchment in south-western England. Natural Hazards and Earth System Sciences, 18, 445461. https://doi.org/10.5194/nhess-18-445-2018

Bromley, R.G., Gale, A.S., 1982. The lithostratigraphy of the English chalk rock. Cretaceous Research, 3, 273306. https://doi.org/10.1016/0195-6671(82)90030-1

Butler, A.P., Hughes, A.G., Jackson, C.R., Ireson, A.M., Wheater, H.S., Peach, D.W., 2014. Advances in modelling groundwater behaviour in Chalk catchments. Geological Society of London, Special Publication, 364, 113-127. https://doi.org/10.1144/SP364.9

Catt, J.A., 1986. The nature, origin, geomorphological significance of Clay-with-flints, in: Sieveking, G., Hart, M.B. (eds), The scientific study of flint and chert, Cambridge University Press, Cambridge, p. 151-159.

Chédeville, S., Laignel, B., Rodet, J., Todisco, D., Fournier, M., Dupuis, E., Girot, G., Hanin, G., 2015. The sedimentary filling in the chalk karst of the Northwestern Paris Basin (Normandy, France): Characterization, origin and hydro-sedimentary behaviour. Zeitschrift für Geomorphologie, 59, 79-101. https://doi.org/10.1127/0372-8854/2014/0139

Coquerel, G., Lefebvre, D., Rodet, J., Staigre, J.C., 1993. La Grotte du Funiculaire (Le Mesnil sous Jumiéges, Seine-Maritime). Spéléogenèse et étude d'un remplissage ferro-magnétique. Karstologia, 22, 35-42. https://doi.org/10.3406/karst.1993.2315

Delbart, C., Valdes, D., Barbecot, F., Tognelli, A., Couchoux, L., 2016. Spatial organization of the impulse response in a karst aquifer. Journal of Hydrology, 537, 18-26. https://doi.org/10.1016/j.jhydrol.2016.03.029

Descamps, F., Faÿ-Gomord, O., Vandycke, S., Schroeder, C., Swennen, R., Tshibangu, J.-P., 2017. Relationships between geomechanical properties and lithotypes in NW European chalks. Geological Society of London, Special Publication, 458, 227-244.

https://doi.org/10.1144/SP458.9

Descostes, M., Pili, E., Felix, O., Frasca, B., Radwan, J., Juery, A., 2012. Diffusive parameters of tritiated water and uranium in chalk. Journal of Hydrology, 452-453, 40-50. https://doi.org/10.1016/j.jhydrol.2012.05.018 Duperret, A., Vandycke, S., Mortimore, R.N., Genter, A., 2012. How plate tectonics is recorded in chalk deposits along the eastern english Channel in Normandy (France) and Sussex (UK). Tectonophysics, 581, 163181. https://doi.org/10.1016/j.tecto.2012.01.021

El Janyani, S., Massei, N., Dupont, J.P., Fournier, M., Dörfliger, N., 2012. Hydrological responses of the chalk aquifer to the regional climatic signal. Journal of Hydrology, 464-465, 485-493. https://doi.org/10.1016/j.jhydrol.2012.07.040

El Janyani, S., Dupont, J.-P., Massei, N., Slimani, S., Dörfliger, N., 2014. Hydrological role of karst in the Chalk aquifer of Upper Normandy, France. Hydrogeology Journal, 22, 663-677. https://doi.org/10.1007/s10040-013-1083-Z

Farrant, A.R., Smart, P.L., 2011. Role of sediment in speleogenesis; sedimentation and paragenesis. Geomorphology, 134(1-2), 79-93.

https://doi.org/10.1016/j.geomorph.2011.06.006

Faÿ-Gomord, O., Descamps, F., Tshibangu, J.P., Vandycke, S., Swennen, R., 2016. Unravelling chalk microtextural properties from indentation tests. Engineering Geology, 209, 30-43.

https://doi.org/10.1016/j.enggeo.2016.05.005

Fournier, M., Massei, M., Mahler, B.J., Bakalowicz, M., Dupont, J.P., 2008. Application of multivariate analyses to suspended matter particle size distribution in a karst aquifer. Hydrogeological Processes, 22, 2267-2274. https://doi.org/10.1002/hyp.6828

Gaillard, T., Hauchard, E., Roux, J.C., 2012. Les Fontaines d'Yport (Seine-Maritime), émergences majeures du littoral normand crayeux. Exploitation et vulnérabilité de la ressource en eau. In : Dixhuitièmes journées techniques du Comité Français d'Hydrogéologie de l'Association Internationale des Hydrogéologues, Cassis, p. 235-244.

Gaillard, T., Lasseur, E., Saïga, J., Dewez, T., Sizun, J.P., Collin, P.Y., 2018. Sédimentologie et pétrophysique de la craie - Impact sur les écoulements actuels dans la Pointe de Caux (France). Géologues, 199, 25-28.

Gale, A.S., 2019. Correlation, age and significance of Turonian Chalk hardgrounds in southern England and northern France: The roles of tectonics, eustasy, erosion and condensation. Cretaceous Research, 103, 104164. https://doi.org/10.1016/j.cretres.2019.06.010

Gallagher, A.J., Rutter, H.K., Buckley, D.K., Molyneux, I., 2012. Litho stratigraphical controls on recharge to the Chalk aquifer of Southern England. Quarterly Journal of Engineering Geology and Hydrogeology, 45, 161-172. https://doi.org/10.1144/1470-9236/09-048

Grube, A., Grube, F., Rickert, B.-H., Strahl, J., 2017. Eemian fossil caves and other karst structures in Cretaceous chalk and succeeding Quaternary sediments covering the salt structure Krempe-Lägerdorf (SW Schleswig-Holstein, North Germany). Zeitschrift der Dtsch. Gesellschaft für Geowissenschaften, 168, 263-284. https://doi.org/10.1127/zdgg/2017/0110

Gupta, S., Collier, J.S., Garcia-Moreno, D., Oggioni, F., Trentesaux, A., Vanneste, K., De Batist, M., Camelbeeck, T., Potter, G., Vliet-lanoe, B. Van, Arthur, J.C.R., 2017. Two-stage opening of the Dover Strait and the origin of island Britain. Nature Communications, 8, 15101. https://doi.org/10.1038/ncomms 15101

Hakoun, V., Orban, P., Dassargues, A., Brouy, S., 2017. Factors controlling spatial and temporal patterns of multiple pesticide compounds in groundwater (Hesbaye chalk aquifer, Belgium). Environmental Pollution, 223, 185-199.

https://doi.org/10.1016/j.envpol.2017.01.012 
Hauchard, E., Laignel, B., 2008. Morphotectonic evolution of the north-western margin of the Paris Basin. Zeitschrift für Geomorphologie, 52, 463-488. https://doi.org/10.1127/0372-8854/2008/0052-0463

Hopson, P.M. 2005. A stratigraphical framework for the Upper Cretaceous Chalk of England and Scotland with statements on the Chalk of Northern Ireland and the UK Offshore Sector. British Geological Survey Research Report, RR/05/01, Keyworth, Nottingham.

Hoyez, B., 2008. Les Falaises du Pays de Caux : lithostratigraphie des craies turono-campaniennes. Publications des Universités de Rouen et du Havre, Mont-Sain-Aignan.

Hoyez, B., 2013. La grotte des Petites Dales. Promenades géologiques dans les falaises blanches de Normandie. https://craies.crihan.fr/?page $\mathrm{id}=12398$, Falaises de Craie [accessed: Octobre 20, 2019].

Juignet, P., 1980. Transgressions-régressions, variations eustatiques et influences tectoniques de l'Aptien au Maastrichtien dans le Bassin de Paris occidental et sur la bordure du Massif Armoricain. Cretaceous Research, 1, 341-357. https://doi.org/10.1016/0195-6671(80)90043-9

Juignet, P., 1991. Les craies du littoral du Pays de Caux. Structures sédimentaires et tectoniques. Bulletin d'information des géologues du Bassin de Paris, 28, 46-58.

Juignet, P., Breton, G., 1992. Mid-cretaceous sequence stratigraphy and sedimentary cyclicity in the western Paris Basin. Palaeogeography Palaeoclimatology Palaeoecology, 91, 197-218. https://doi.org/10.1016/0031-0182(92)90067-F

Keim, D.M., West, L.J., Odling, N.E., 2012. Convergent flow in unsaturated fractured Chalk. Vadose Zone Journal, 11(4), vzj2011.0146.

https://doi.org/10.2136/vzj2011.0146

Kennedy, W.J., Juignet, P., 1974. Carbonate banks and slumpbeds in the Upper Cretaceous (Upper Turonian- Santonian) of Haute Normandie, France. Sedimentology, 21, 1-42.

https://doi.org/10.1111/j.1365-3091.1974.tb01780.x

Kennedy, W.J., Garrison, R.E., 1975. Morphology and genesis of nodular chalks and hardgrounds in the Upper Cretaceous of southern England. Sedimentology, 22, 311-386.

https://doi.org/10.1111/j.1365-3091.1975.tb01637.x

Klimchouk, A., 2006. Unconfined versus confined speleogenetic settings: variations of solution porosity. International Journal of Speleology, 35, 19-24. https://doi.org/10.5038/1827-806X.35.1.3

Laignel, B., Dupuis, E., Rodet, J., Lacroix, L., Massei, N., 2004. An example of sedimentary filling in the chalk karst of the Western Parias Basin characterization, origins and hydrosedimentary behaviour. Zeitschrift für Geomorphologie, 48(2), 219-243.

Lamont-Black, J., Mortimore, R., 2000. Dissolution tubules: A new karst structure from the English chalk. Zeitschrift für Geomorphologie, 44(4), 469-489.

Lasseur, E., Guillocheau, F., Robin, C., Hanot, F., Vaslet, D., Coueffe, R., Neraudeau, D., 2009. A relative waterdepth model for the Normandy Chalk (CenomanianMiddle Coniacian, Paris Basin, France) based on facies patterns of metre-scale cycles. Sedimentary Geology, 213(1-2), 1-26. https://doi.org/10.1016/j.sedgeo.2008.10.007

Le Vine, N., Butler, A., Mcintyre, N., Jackson, C., 2016. Diagnosing hydrological limitations of a land surface model: application of JULES to a deep-groundwater chalk basin. Hydrology and Earth System Sciences, 20, 143-159. https://doi.org/10.5194/hess-20-143-2016
Lowe, J., Gunn, J., 1995. The role of strong acid in speleo-inception and subsequent cavern development. In: Baranay-Kevei, I., Lucsi, L. (Eds.), Special Issue, Acta Geographica 24, 33-60.

Lowe, D.J., 2000. Role of stratigraphic element in speleogenesis: the speleoinception concept. In: Klimchouk, A.B., Ford, D.C., Palmer, A.N., Dreybrodt, W. (Eds.), Speleogenesis. Evolution of karst aquifers. National Speleological Society, Huntsville, p. 65-76.

MacDonald, A.M., Brewerton, L.J., Allen, D.J., 1998. Evidence for rapid groundwater flow and karst-type behaviour in the Chalk of southern England. Geological Society of London, Special Publications, 130, 95-106. https://doi.org/10.1144/GSL.SP.1998.130.01.09

Mangin, A., 1975. Constitution et fonctionnement des aquifères karstiques. Annales de Spéléologie, 30(1), 21-124.

Maurice, L.D., Atkinson, T.C., Farrant, A.R., Williams, A.T., 2006. Karstic behaviour of groundwater in the English Chalk. Journal of Hydrology, 330, 63-70. https://doi.org/10.1016/j.jhydrol.2006.04.012

Maurice, L.D., Atkinson, T.C., Barker, J.A., Williams, A.T., Gallagher, A.J., 2012. The nature and distribution of flowing features in a weakly karstified porous limestone aquifer. Journal of Hydrology, 438-439, 3-15. https://doi.org/10.1016/j.jhydrol.2011.11.050

Mocochain, L., Audra, P., Clauzon, G., Bellier, O., Bigot, J.Y., Parize, O., Monteil, P., 2009. The effect of river dynamics induced by the Messinian Salinity Crisis on karst landscape and caves: Example of the Lower Ardèche river (mid Rhône valley). Geomorphology, 106, 46-61. https://doi.org/10.1016/j.geomorph.2008.09.021

Mortimore, R.N., 1993. Chalk water and engineering geology. In: Downing, R.A., Price, M., Jones, G.P. (Eds.), The hydrogeology of the Chalk of North-West Europe. Oxford Science Publications, Oxford, p. 67-92.

Mortimore, R.N., 1986. Stratigraphy of the Upper Cretaceous White Chalk of Sussex. Proceedings of the Geologists' Association, 97, 97-139. https://doi.org/10.1016/S0016-7878(86)80065-7

Mortimore, R.N., 2011. A chalk revolution: What have we done to the Chalk of England? Proceedings of the Geologists' Association, 122, 232-297.

https://doi.org/10.1016/j.pgeola.2010.09.001

Mortimore, R.N., 2019. Late Cretaceous to Miocene and Quaternary deformation history of the Chalk: Channels, slumps, faults, folds and glacitectonics. Proceedings of the Geologists' Association, 130, 27-65. https://doi.org/10.1016/j.pgeola.2018.01.004

Mortimore, R.N., Pomerol, B., 1987. Correlation of the Upper Cretaceous White Chalk (Turonian to Campanian) in the Anglo-Paris Basin. Proceedings of the Geologists' Association, 98(2), 97-143. https://doi.org/10.1016/S0016-7878(87)80001-9

Mortimore, R.N., Wood, C.J., Gallois, R.W. 2001. British Upper Cretaceous Stratigraphy. Geological Conservation Review Series, No. 23. Joint Nature Conservation Committee, Peterborough.

Mougin, B., Branellec, M., David, P.Y., Zammit, C., Bourgine, B., 2011. Atlas hydrogéologique régional de Haute-Normandie Cartes piézométriques de l'aquifère crayeux. Atlas hydrogéologique régional de Haute-Normandie Cartes piézométriques de l'aquifère crayeux. BRGM, Orléans.

Nader, F.H., De Boever, E., Gasparrini, M., Liberati, M., Dumont, C., Ceriani, A., Morad, S., Lerat, O., Doligez, B., 2013. Quantification of diagenesis impact on the reservoir properties of the Jurassic Arab D and C members (Offshore, U.A.E.). Geofluids, 13, 204-220. https://doi.org/10.1111/gfl.12022 
Nehme, C., Farrant, A., Ballesteros, D., Todisco, D., Rodet, J., Sahy, D., Grappone, J.M., Staigre, J.C., Mouralis, D. 2020. Reconstructing fluvial incision rates based on palaeo-water tables in chalk karst networks along the Seine valley (Normandy, France). Earth Surface Processes and Landforms, 45, 1860-1876. https://doi.org/10.1002/esp.4851

Palmer, A., 1991. Origin and morphology of limestone caves. Geological Society of America Bulletin, 103, 1-21. https://doi.org/10.1130/0016-7606(1991)103\% 3C0001:OAMOLC\%3E2.3.CO;2

Pasini, G. 2009. A terminological matter: paragenesis, antigravitative erosion or antigravitational erosion? International Journal of Speleology, 38(2), 129-238. https://doi.org/10.5038/1827-806X.38.2.4

Pennequin, D., David, P., Servière, M., Amraoui, N., 2017. Hydro-System Flow Modelling for Water Resources Management in the fractured and karstified chalk aquifer environment of Eastern Normandy. In: Renard, P., Bertrand, C. (Eds.), EuroKarst 2016, Neuchâtel, Advances in Karst Science. Neuchâtel, p. 217-229. https://doi.org/10.1007/978-3-319-45465-8_22

Pennos, C., Lauritzen, S.E., Vouvalidis, K., Cowie, P., Pechlivanidou, S., Gkarlaouni, C., Styllas, M., Tsourlos, P., Mouratidis, P., 2019. From subsurface to surface: a multidisciplinary approach to decoding uplift histories in tectonically-active karst landscapes. Earth Surface Processes and Landforms, 44, 1710-1721.

https://doi.org/10.1002/esp.4605

Piccini, L., 2011. Recent development on morphometric analysis of karst caves. Acta Carsologica, 40, 43-52. https://doi.org/10.3986/ac.v40i1.27

Price, M., Bird, M.J., Foster, S.S.D., 1976. Chalk poresize measurements and their significance. Water Services, p. 596-600.

Price, M., Downing, R.A., Edmunds, W.M., 1993. The Chalk as an aquifer. In: Downing, R.A., Price, M., Jones, G.P. (Eds), The hydrogeology of the Chalk of north-west Europe. Clarendon Press, Oxford, p. 14-34.

Price, M., Low, R.G., McCann, C. 2000. Mechanisms of water storage and flow in the unsaturated zone of the Chalk aquifer. Journal of Hydrology, 233, 54-71. https://doi.org/10.1016/S0022-1694(00)00222-5

Quesnel, F., Catt, J., Laignel, B., Bourdillon, C., Meyer, R., 2003. The Neogene and Quaternary Clay-with-flints north and south of the English Channel: Comparisons of distribution, age, genetic processes and geodynamics. Journal of Quaternary Science, 18, 283-294. https://doi.org/10.1002/jqs.753

Quesnel, F., Couëffé, R., Duriez, M., Lasseur, E., 2008. Carte géologique harmonisée du département de la Seine-Maritime Notice technique. Bureau de Recherches Géologiques et Minières, Paris.

Quince, M., Bosence, D., 1991. Stratal geometries, facies and sea-floor erosion in Upper Cretaceous Chalk, Normandy, France. Sedimentology, 38, 1113-1152. https://doi.org/10.1111/j.1365-3091.1991.tb00375.x

Rahman, A.S.M.M., Rosolem, R., 2017. Towards a simple representation of chalk hydrology in land surface modelling. Hydrology and Earth System Sciences, 21, 459-471. https://doi.org/10.5194/hess-21-459-2017

Rodet, J., 2007. Karst de la craie et aquifère de Normandie. European Journal of Water Quality, 38, 11-22. https://doi.org/10.1051/wqual/2007008

Rodet, J., 2013. Karst et évolution géomorphologique de la côte crayeuse à falaises de la manche. L'exemple du massif d'aval (Étretat, Normandie, France). Quaternaire, 24, 303-314.

https://doi.org/10.4000/quaternaire.6745
Rodet, J., Staigre, J., 2019. Désobstruction et spéléologie en Normandie, in: Actes du Premier Colloque Francophone 'Histoires de Désob'. Azé, p. 180-207.

Rodet, J., Viard, J.P. 2009. La Grotte des Petites Dales, un patrimoine normal? Non! Normand! Spelunca, 114, 28-34.

Rodet, J., Laignel, B., Brocard, G., Dupuis, E., Massei, N., Viard, J., 2006. Contribution of a sedimentary study to the concept of karstic evolution of a chalk cave in the western Paris basin (Normandy, France). Geologica Belgica, 9, 287-296.

Roux, J.C., Gaillard, T., Hauchard, E., 2019. Le système hydrogéologique karstique crayeux des sources d'Yport (Seine- Maritime). Évolution des connaissances et exploitation de la ressource. Géologues, 199, 73-82.

Saïag, J., 2016., Caractérisation des hétérogénéités sédimentaires et pétrophysiques d'un réservoir carbonaté microporeux. Le cas de la Craie (Crétacé supérieur, Bassin de Paris). PhD Thesis, University of Bourgogne, Dijon (NNT: 2016DIJOS039).

Saïag, J., Collin, P.Y., Sizun, J.P., Herbst, F., FaÿGomord, O., Chateau Smith, C., Caline, B., Lasseur, É., 2019. Classifying chalk microtextures: Sedimentary versus diagenetic origin (Cenomanian-Santonian, Paris Basin, France). Sedimentology, 66, 2976-3007. https://doi.org/10.1111/sed.12618

Slimani, S., Massei, N., Mesquita, J., Valdés, D., Fournier, M., Laignel, B., Dupont, J.P., 2009. Combined climatic and geological forcings on the spatio-temporal variability of piezometric levels in the chalk aquifer of Upper Normandy (France) at pluridecennal scale. Hydrogeology Journal, 17, 1823-1832.

https://doi.org/10.1007/s10040-009-0488-1

Thiéry, D., Amraoui, N., Noyer, M.L., 2018. Modelling flow and heat transfer through unsaturated chalk Validation with experimental data from the ground surface to the aquifer. Journal of Hydrology, 556, 660673. https://doi.org/10.1016/j.jhydrol.2017.11.041

Valdes, D., Dupont, J.P., Laignel, B., Slimani, S., Delbart, C., 2014. Infiltration processes in karstic chalk investigated through a spatial analysis of the geochemical properties of the groundwater: The effect of the superficial layer of clay-with-flints. Journal of Hydrology, 519, 23-33. https://doi.org/10.1016/j.jhydrol.2014.07.002

Van Buchem, F.S.P., Smit, F.W.H., Buijs, G.J.A., Trudgill, B., Larsen, P.H., 2017. Tectonostratigraphic framework and depositional history of the Cretaceous-Danian succession of the Danish Central Graben (North Sea) - new light on a mature area. In: Bowman, M., Levell, B. (Eds.), Petroleum Geology of NW Europe: 50 Years of Learning - Proceedings of the 8th Petroleum Geology Conference. The Geological Society, London, p. 9-146. https://doi.org/10.1144/PGC8.24

Van Lint, J., Giot, D., Callec, Y., 2003. Carte géologique harmonisée du département de l'Eure. Bureau de Recherches Géologiques et Minières, Paris.

Waltham, A.C., Simms, M.J., Farrant, A.R., Goldie, H.S., 1997. Karst and caves of Great Britain. Chapman and Hall. Joint Nature Conservation Committee.

Weng, P., Coudrain-Ribstein, A., Talbi, A., Bendjoudi, H., 1999. Groundwater circulations between alluvial aquifer and underlying Senonian Chalk in the Seine Valley. Physics and Chemistry of the Earth, 24, 151154. https://doi.org/10.1016/S1464-1909(98)00027-6

Woods, M.A., 2015. Applied palaeontology in the Chalk Group: Quality control for geological mapping and modelling and revealing new understanding. Proceedings of the Geological Association, 126, 777787. https://doi.org/10.1016/j.pgeola.2015.11.003 
Wray, D.S., 1999. Identification and long-range correlation of bentonites in Turonian-Coniacian (Upper Cretaceous) chalks of northwest Europe. Geological Magazine, 136, 361-371.

https://doi.org/10.1017/S0016756899002836

Zghibi, A., Zouhri, L., Chenini, I., Merzougui, A., Tarhouni, J., 2016. Modelling of the groundwater flow and of tracer movement in the porous and fissured media: Chalk Aquifer (Northern part of Paris Basin, France). Hydrogeological Processes, 30, 1916-1928. https://doi.org/10.1002/hyp.10746

Zouhri, L., Smaoui, H., Carlier, E., Ouahsine, A., 2009. Modelling of hydrodispersive processes in the fissured media by flux limiters schemes (Chalk aquifer, France). Mathematical and Computer Modelling, 50, 516-525. https://doi.org/10.1016/j.mcm.2009.04.008 